Review

\title{
Biodegradable Materials for Bone Repair and Tissue Engineering Applications
}

\section{Zeeshan Sheikh ${ }^{1, *}$, Shariq Najeeb ${ }^{2}$, Zohaib Khurshid ${ }^{3,4}$, Vivek Verma ${ }^{5}$, Haroon Rashid ${ }^{6}$ and Michael Glogauer ${ }^{7}$}

${ }^{1}$ Faculty of Dentistry, Matrix Dynamics Group, University of Toronto, 150 College Street, Toronto, ON M5S 3E2, Canada

${ }^{2}$ School of Clinical Dentistry, University of Sheffield, Sheffield S10 2TN, UK;

E-Mail: shariqnajeeb@gmail.com

${ }^{3}$ School of Materials and Metallurgy, University of Birmingham, Birmingham B15 2TT, UK; E-Mail: drzohaibkhurshid@gmail.com

${ }^{4}$ Biomaterials Department of Biomedical Engineering, School of Engineering, King Faisal University, Al-Hofuf 31982, Saudi Arabia

${ }^{5}$ Faculty of Dentistry, Division of Biomedical Sciences, McGill University, 2001 McGill College Avenue, Montreal, QC H3A 1G1, Canada; E-Mail: vivek.verma@mail.mcgill.ca

${ }^{6}$ College of Dentistry, Division of Prosthodontics, Ziauddin University, 4/B, Clifton, Karachi 7550, Pakistan; E-Mail: drh.rashid@hotmail.com

${ }^{7}$ Matrix Dynamics Group, Faculty of Dentistry, University of Toronto, 150 College Street, Toronto, ON M5S 3E2, Canada; E-Mail: Michael.Glogauer@utoronto.ca

* Author to whom correspondence should be addressed; E-Mail: zeeshan.sheikh@ utoronto.ca; Tel.: +1-514-224-7490.

Academic Editor: C. Edi Tanase

Received: 15 July 2015 / Accepted: 24 August 2015 / Published: 31 August 2015

\begin{abstract}
This review discusses and summarizes the recent developments and advances in the use of biodegradable materials for bone repair purposes. The choice between using degradable and non-degradable devices for orthopedic and maxillofacial applications must be carefully weighed. Traditional biodegradable devices for osteosynthesis have been successful in low or mild load bearing applications. However, continuing research and recent developments in the field of material science has resulted in development of biomaterials with improved strength and mechanical properties. For this purpose, biodegradable materials, including polymers, ceramics and magnesium alloys have attracted
\end{abstract}


much attention for osteologic repair and applications. The next generation of biodegradable materials would benefit from recent knowledge gained regarding cell material interactions, with better control of interfacing between the material and the surrounding bone tissue. The next generations of biodegradable materials for bone repair and regeneration applications require better control of interfacing between the material and the surrounding bone tissue. Also, the mechanical properties and degradation/resorption profiles of these materials require further improvement to broaden their use and achieve better clinical results.

Keywords: biomaterials; biodegradable materials; bone regeneration; bone repair; tissue engineering

\section{Introduction}

Bone is a composite natural living tissue which comprises of an organic phase in which calcium containing inorganic phase crystals are embedded [1]. Bone by weight contains about $30 \%$ matrix, $60 \%$ mineral and $10 \%$ water [2]. The bone matrix is primarily collagen which responsible for the tensile strength. The mineral component of bone is calcium phosphate, which imparts compressive strength to the bone tissue [3]. There are two types of bone tissue, cortical (compact), and cancellous (trabecular). Compact bone has Young's modulus of elasticity ranging from 17-20 GPa and compressive strength in the range of 131-224 MPa [2,4], while Young's modulus and compressive strength for trabecular bones are 50-100 MPa and 5-10 MPa respectively $[2,4]$.

Bone tissue is susceptible to fracture as a result of trauma, pathology and resorption [5,6]. Bone fixation and repair devices traditionally are fabricated with metals and used clinically [7,8]. Stainless steel, titanium and its alloys have been employed for the majority of fracture fixation treatments $[9,10]$. However these metallic devices and implants are not biodegradable and often require a second surgery in order to remove these from the body [10-12]. This not only increases the hospitalization time and health care cost but also elevates chances of infection and complications. Also, due to the mismatch between the mechanical properties of these devices and the natural bone, mechanical forces and loads are retained by implants and are not transferred to the healing bone [13]. This is termed as "stress shielding" which results in unwanted bone resorption and implant loosening [13-16]. Bone defect management involves using autologous bone graft which is harvested from various sites of the patient body $[17,18]$. Autologous bone grafting is considered as the gold standard and it possesses all the characteristics necessary for new bone growth, i.e., (i) osteoconductivity (scaffold to promote bone apposition) [19]; (ii) osteogenicity (containing osteoprogenitor cells) [20] and (iii) osteoinductivity (provide signals to induce osteogenic differentiations of local stem cells) [21,22]. However, there are limitations and concerns of this approach such as, limited bone supply, donor site morbidity, anatomical, structural and surgical limitations and increased bone resorption during healing [23-27]. Other biological sources, such as allograft and xenogenic bone has also been evaluated and used with varying clinical success for bone repair and regeneration [6,28]. The use of synthetic materials (alloplasts) is another way to repair and regenerate lost bone tissue $[29,30]$. 
According to the degradation performance, materials for bone repair can be classified into two groups: bio-inert and biodegradable materials [31,32]. The bio-inert materials have been used widely for clinical use with success; they do have some problems. For example, they are mostly inert implants that stay in human body forever until removed surgically. A major drive for continued research to develop biodegradable materials is the need for new materials with properties tailored to meet the biochemical and biomechanical requirements of bone tissue engineering [31-34]. The basic concept is that the substitute biomaterial acts as a scaffold for the surrounding cells/tissue to invade, grow, and thus guide tissue regeneration towards new bone formation [35-39]. Once bone repair and healing has occurred, scaffold removal via in vivo degradation is desirable both from a clinical and a biomechanical point of view. Therefore, biodegradable materials are sought since they can be used as an implant and do not require a second surgical event for removal [40,41]. The biodegradable materials must support the bone tissue regeneration and repair process while providing mechanical support and degrading to non-toxic products ultimately being removed by the body [42]. While providing a brief introduction to chemistry and properties of major classes of materials, the main aim of this review is to provide the readers with an update on recent developments in different classes of biodegradable materials for bone repair applications.

\section{Biodegradable Materials}

There are a variety of biomaterials that have been researched upon and used clinically for bone repair and regeneration applications [43]. The degradation of implant materials is accompanied with an unwanted decrease in mechanical properties. However, if the degradation is controlled and gradual, then the loads will transfer from the implants to bone tissue and soft tissues to avoid the stress shield effect $[15,42]$. The development of biodegradable rods, plates, pins, screws and suture anchors has progressed in recent years. Biodegradable polymers, ceramics and metals are the main three kinds of widely studied and clinically used biodegradable materials (Table 1). In this section, these biodegradable materials are reviewed and recent advancements summarized. 
Table 1. Physical properties of natural bone tissue compared with other degradable and non-degradable materials and their applications $[2,4,9,44-50]$.

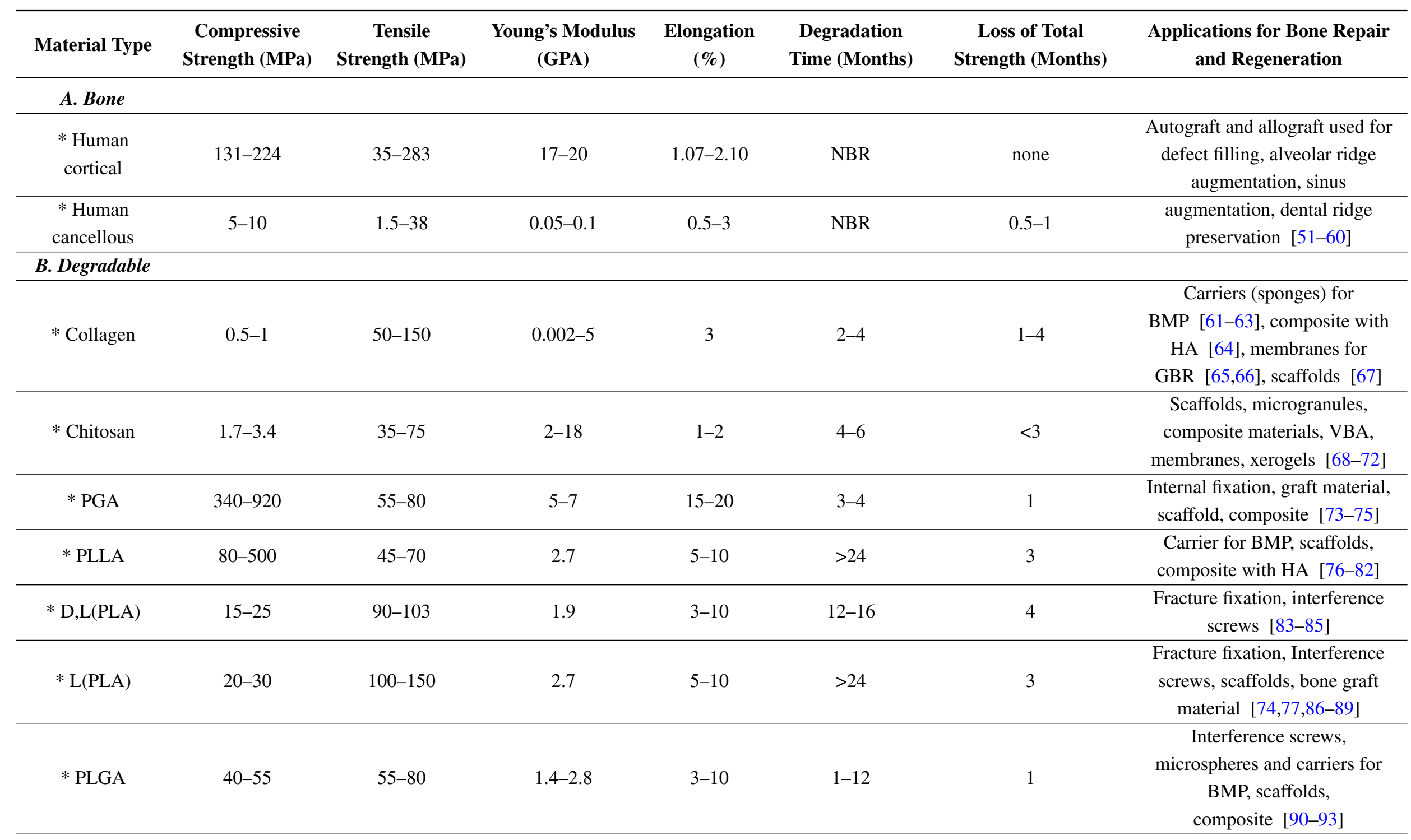


Table 1. Cont

\begin{tabular}{|c|c|c|c|c|c|c|c|}
\hline Material Type & $\begin{array}{c}\text { Compressive } \\
\text { Strength (MPa) }\end{array}$ & $\begin{array}{c}\text { Tensile } \\
\text { Strength (MPa) }\end{array}$ & $\begin{array}{l}\text { Young's Modulus } \\
\text { (GPA) }\end{array}$ & $\begin{array}{c}\text { Elongation } \\
(\%)\end{array}$ & $\begin{array}{c}\text { Degradation } \\
\text { Time (Months) }\end{array}$ & $\begin{array}{c}\text { Loss of Total } \\
\text { Strength (Months) }\end{array}$ & $\begin{array}{c}\text { Applications for Bone Repair } \\
\text { and Regeneration }\end{array}$ \\
\hline$* \mathrm{PCL}$ & $20-40$ & $10-35$ & $0.4-0.6$ & $300-500$ & $>24$ & $>6$ & $\begin{array}{l}\text { Scaffolds and composites with } \\
\text { HA fillers [94-99] }\end{array}$ \\
\hline * Hydroxyapatite & $500-1000$ & $40-200$ & $80-110$ & $0.5-1$ & $>24$ & $>12$ & $\begin{array}{l}\text { Scaffolds, composites, bone } \\
\text { fillers (granules and blocks), } \\
\text { pastes, vertebroplasty, drug } \\
\text { delivery, coatings [100-111] }\end{array}$ \\
\hline$* \mathrm{TCP}$ & 154 & $25-80$ & $60-75$ & $1-2$ & $>24$ & $1-6$ & $\begin{array}{l}\text { Bone fillers, injectable pastes, } \\
\text { cements }[112-122]\end{array}$ \\
\hline * Brushite & $35-60$ & $15-25$ & $40-55$ & $2-3$ & $>24$ & $1-6$ & $\begin{array}{l}\text { Drug delivery, restoration of } \\
\text { metaphyseal defects, ligament } \\
\text { anchor, reinforcement of }\end{array}$ \\
\hline * Monetite & $15-25$ & $10-15$ & $22-35$ & $3-4$ & $3-6$ & $1-3$ & $\begin{array}{l}\text { Osteosynthesis screws, ridge } \\
\text { preservation, vertical bone } \\
\text { augmentation, defect filling, } \\
\text { vertebroplasty [123-143] }\end{array}$ \\
\hline * Magnesium & $65-1000$ & $135-285$ & $41-45$ & $2-10$ & 0.25 & $<1$ & $\begin{array}{l}\text { Implants, osteosynthesis devices, } \\
\text { plates, screws, ligatures, and } \\
\text { wires }[122,144-158]\end{array}$ \\
\hline \multicolumn{8}{|l|}{ C. Non-Degradable } \\
\hline * Titanium alloy & 900 & $900-1000$ & $110-127$ & $10-15$ & No & None & $\begin{array}{l}\text { Implants, plates, screws, BMP } \\
\text { carriers, orthognathic surgery, } \\
\text { mid-facial fracture } \\
\text { treatment [159-166] }\end{array}$ \\
\hline * Stainless Steel & $500-1000$ & $460-1700$ & $180-205$ & $10-40$ & No & None & $\begin{array}{l}\text { Implants, plates, mini-plates, } \\
\text { screws }[167-170]\end{array}$ \\
\hline * Bioglass & $40-60$ & $120-250$ & 35 & $0-1$ & No & None & Bone defect fillers [171-177] \\
\hline
\end{tabular}

NBR: Natural bone remodeling; PGA: Poly glycolic acid; PLLA: Poly L-lactic acid; PLGA: Poly lactic glycolic acid; PCL: Poly caprolactone; PLA: Poly lactic acid; PEO: Poly ethylene oxide; BMP: bone morphogenetic proteins; GBR: guided bone regeneration; VBA: vertical bone augmentation; HA: hydroxyapatite. 


\subsection{Polymers}

Polymers are macromolecules that are composed of covalently bonded repeating monomers that can be same or different, i.e., homopolymers and copolymers [178]. These materials can be amorphous and crystalline with chains being linear, branched or cross-linked with other chains [179]. Polymer properties are affected by temperature and it is important to synthesize biodegradable polymers with the glass transition temperature $\left(T_{\mathrm{g}}\right)$ above the body temperature as polymers become very flexible above their defined $T_{\mathrm{g}}$ [178].

Biodegradable polymers are one of the primary and common biomaterials used for bone repair and tissue engineering. Their biodegradability and controlled degradation rates are highly beneficial for clinical applications $[180,181]$. The degradation of polymeric materials can be altered by changing their structural composition and fabrication techniques [179]. The degradation process and rate is affected by various factors such as the molecular composition molecular weight $(\mathrm{Mw})$ and crystallinity $[80,182]$. The types of monomers making up the polymeric material affect the sensitivity of hydrolysable bonds [9]. The longer the polymer chains are the more hydrolytic chain scissions are required to obtain biodegradation. Since crystallinity is the measure of organization, interactions and packing in a material affects biodegradation, more crystalline materials possess stronger inter- and intra-molecular bonding therefor degrade slowly when compared to amorphous polymers [42].

An optimal interaction on a cellular and biochemical level is required for a positive outcome to be achieved towards the formation of a functional tissue [79]. There are a few criteria for biodegradable polymers in order to be used successfully for bone repair and tissue engineering applications: (i) the polymer surface should allow for cell adhesion and growth to occur; (ii) post implantation in vivo, there should be no inflammatory or toxic response towards the polymer or its degradation products; (iii) have sufficiently high porosity that is interconnected; (iv) have high surface area and adequate space for extracellular matrix; (v) be completely degradable with controlled resorption timing of the scaffold matrix (degradation rate ideally matching with the regenerating bone tissue); and lastly (vi) the polymeric material should allow reproducible processing into three dimensional (3D) structures $[35,79,183]$.

Based on their origin, polymers can be classified as natural or synthetic. Due to their inherent low strength, natural polymers are mainly used for the repair of small bone fractures that do not impart high loads onto the implant materials. As for the synthetic polymers, by controlling the design and synthesis, polymers with improved mechanical properties can be prepared [184,185]. Synthetic polymers also have the advantage of having a well-controlled and reproducible molecular structure and are also non-immunogenic.

\subsubsection{Natural Biodegradable Polymers}

Collagen

Collagen is the most abundant protein present in the human body and is the major component in bone and skin tissues [186,187]. Collagen is a polymer with repeating sequences having a molecular weight $\left(M_{\mathrm{w}}\right)$ of 300,000 and a chain length of $300 \mathrm{~nm}$. The repeating sequences of collagen are responsible for the helical structure and inherent mechanical strength [188]. Due to the fact that collagen undergoes enzymatic degradation in the body, the mechanical and biological properties of collagen have been 
thoroughly studied for biomedical applications. The collagen rate of degradation can be controlled and altered introducing cross-linking in the polymer chains and also by enzymatic pre-treatments [189].

Collagen when used as a biomaterial is biocompatible, biodegradable and osteoconductive [190,191]. Collagen can be processed into different forms such as tubes, sheets, nano-fiber matrices, foams, powders and viscous solutions and dispersions that are injectable [79]. Human bone is a mineral/organic natural composite consisting of hydroxyapatite (HA) and collagen (mainly). Hence, composites produced using calcium phosphates and collagens are considered as the most biomimetic system for osseous replacement and regenerative applications [192-196]. Calcium phosphate particles when mixed with collagen result in easily moldable biomaterials for clinical use [197]. Collagen coatings on calcium phosphate substrates and implants have been shown to facilitate and enhance early cell adhesion and proliferation [198,199]. This results in increased osteoconduction, osteointegration and bone formative capacity of these materials when implanted in vivo $[198,199]$. For these particular advantages, calcium phosphate and collagen containing composite materials have been developed [200] via particle-gel mixing and powder compression methods [201-203].

Additives such as citric acid when are added to collagen and used to set dicalcium phosphate dehydrate (DCPD) also known as brushite, it is observed that the speed setting reaction is increased significantly and the hardened biomaterials has compressive strength similar to cancellous bone (48.0 MPa) [44]. Addition of citric acid also increases the workability of the collagen-brushite cement paste and enables the mixing of high collagen gel (3 wt \%) with the cement powders. With this combination using citric acid, the setting time was shortened along with a decrease in viscosity which enhances injectibility of the composite [204]. The effect of introducing cross-linking into the collagen-brushite composite phase was also investigated by immersion of the biomaterial into gluteraldehyde solution (2\%). However, this immersion was not shown to increase the compressive strength of the composite materials [44].

\section{Chitosan}

Chitosan is a natural biopolymer derived from chitin. It is a linear polysaccharide, composed of glucosamine and $\mathrm{N}$-acetyl glucosamine in a particular ratio [205]. The molecular weight of chitosan may range from 300 to $1000 \mathrm{kDa}$ depending on its source and processing methods. Although chitosan is generally insoluble in aqueous solutions above $\mathrm{pH} 7$, but when placed in diluted acids having $\mathrm{pH}$ less than 6, the protonated free amino group of glucosamine facilitates the solubility of the material [206-208]. Chitosanase, papain and lyzozyme are known to degrade chitosan in vitro [161]. The in vivo degradation takes place primarily due to lyzozyme and is regulated via hydrolysis of the acetylated residues. The chitosan degradation rate depends on the level of crystallinity and acetylation of the polymer [209]. The chemical alteration of chitosan polymer can affect degradation and solubility rate significantly and the highly deacetylated form demonstrates slow biodegradation occurring over several months in vivo [209].

Chitosan is biocompatible and can be molded to form structures and scaffolds having porous micro-architecture which promotes osteoconduction [210]. Chitosan with calcium phosphate have been researched upon for this purpose. Scaffolds containing high molecular weight chitosan demonstrated superior mechanical properties compared with scaffolds constructed with medium molecular weight chitosan [210]. Chitosan/nano-crystalline calcium phosphate based scaffolds have rough surface and 
20 times greater surface area per unit mass than chitosan scaffolds alone [211]. This increase in roughness and surface area results in greater protein adsorption, cell attachment and proliferation for bone regeneration and repair applications [211]. Also, these scaffolds have better mechanical properties which can be attributed to the better dispersion and strong interaction of calcium phosphate nano-crystals with chitsoan [211]. Collagen has been incorporated into chitosan to form composite micro-granules to be used as bone substitutes. The micro-granular structure allows for close packing into defects and the interconnected pores in between the micro-granules allow for new bone and vascular ingrowth [68,69]. The addition of filler particles such as HA to these chitosan/collagen composite biomaterials improves mechanical strength significantly [70].

Chitosan membranes fabricated with silica xerogels have been evaluated for applications in guided bone regeneration (GBR) with regards to bone regeneration ability [212]. Significantly enhanced new bone formation has been observed using the chitosan/slica xerogel membranes compared with pure chitosan membranes alone [71]. Also, after 3 weeks the histomorphometric analysis revealed that the defect was completely healed with the hybrid membrane, whereas on $\sim 57 \%$ of defect closure was observed with chitosan membrane used alone [212]. In another study sulfated chitosan with varied sulfate groups, sulfur content and molecular weight were investigated to see the effect of being tailored on bioactivity of bone morphogenetic protein 2 (BMP-2) [213]. Osteoblast differentiation was stimulated in vitro and ectopic bone formation was induced in vivo by low dose of synthetic sulfated chitosan [213].

\subsubsection{Synthetic Biodegradable Polymers}

The most extensively researched upon synthetic biodegradable polymers are Poly ( $\alpha$-hydroxy acids) also known as polyesters. These synthetic polymers can be synthesized from a wide range of monomeric units via ring opening and condensation polymerization methods. Poly (hydroxyl acid) has an ester bond that is cleaved by hydrolysis which results in a reduction in the molecular weight $\left(M_{\mathrm{w}}\right)$ of the polymer [214]. However, this reduction in $M_{\mathrm{w}}$ does not decrease the mass of the implant materials. The rate of degradation of polyesters is dependent on the exposed surface area, crystallinity, initial $M_{\mathrm{w}}$ and the ratio between hydroxyl ions and the monomers (in copolymers) [186].

The most extensively investigated and used polymers among the poly ( $\alpha$-hydroxy acid) class are the poly (glycolic acid) (PGA), poly (lactic acid) (PLA) and their copolymer poly (lactic-co-glycolide) (PLGA) [43,215-218]. Apart from PGA, these polymers are soluble a variety of organic solvents and hence can be processed by many solvent and thermal-based methods [219,220]. These polymers are considered to be suitable candidates for bone repair and regeneration applications since they are biocompatible with and biodegradable in the human body [187]. The biodegradation is mediated via hydrolytic degradation through the process of de-esterification and the removal of monomeric byproducts takes place through natural excretory pathways [220,221]. Through the method of esterification all polyesters, theoretically, can be made degradable. However, it is a chemically reversible process and only aliphatic chains between ester bonds can degrade in the time that is required in order to be useful for biomedical applications [214].

Implantable devices for internal fixation for fracture repair have been fabricated using these polymers and have gained popularity [222]. They first generated interest three decades ago when polyesters were utilized for suture materials and still remain one of the widely used synthetic biodegradable 
polymers [223]. When polyesters are used alone for the fabrication of devices the mechanical properties of highly porous scaffolds are relatively weak than that required for bone tissue engineering applications [224]. They also lower the local $\mathrm{pH}$ in vivo due to the degradation products that in turn accelerates the degradation rate of the implants to an extent that limits their clinical usefulness [225]. Another disadvantage of this rapid disintegration is that the acidic degradation byproducts (monomeric or oligomeric hydroxyl-carboxylic acids) induce an inflammatory reaction [226-228].

Poly (Glycolic Acid)

Poly (glycolic acid) (PGA) is a highly crystalline synthetic polymer (45\%-50\% crystallinity) of glycolic acid (Figure 1). Due to the high crystallinity, melting point $\left(>200{ }^{\circ} \mathrm{C}\right.$ ), tensile modulus and controlled solubility, PGA was first employed for clinical use as sutures and as biomedical implants [229]. PGA has a high degradation rate due to its hydrophilic nature and the mechanical strength of PGA after implantation for 14 days usually decreases by $50 \%$ and by 90\% after 28 days [47]. The degradation product of PGA is hydroxyacetic acid and is either metabolized by the liver (as $\mathrm{CO}_{2}$ and $\mathrm{H}_{2} \mathrm{O}$ as final products) or discharged through the kidneys via the urine [230]. Biodegradation, no aggregation and lack of cytotoxic response are the main advantages of using PGA as a degradable biomaterial $[231,232]$.

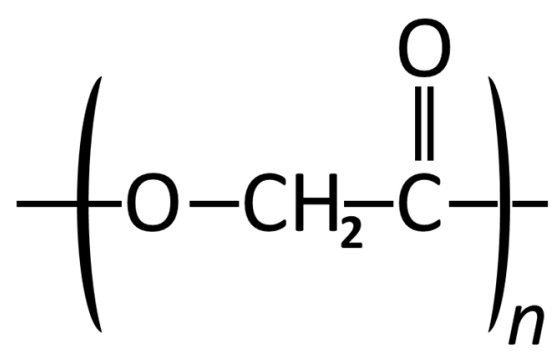

Figure 1. Structural formula of Poly glycolic acid.

PGA has been used as a self-reinforced foam and is stiffer (Young's modulus of 12.5 GPa) [233] than other degradable polymers for clinical use [73]. Also, PGA loses its mass in 6-12 months due to in vivo degradation [79]. PGA has been evaluated as a biomaterial for fabrication of devices used for internal fixation of bone [74,234]. Since PGA loses its strength after implantation with time, this limits their usefulness for load bearing fractured segments [79]. PGA has also been reinforced with amorphous carbonated-apatite and used as a bone replacement graft material but it was observed that this material was only useful in small defects or non-loading bearing situations [75].

Poly (Lactic Acid)

Poly (lactic acid) (PLA) was first used for medical applications as sutures and rods for the treatment of mandibular fractures in dogs [235], and since has been researched upon extensively [236-238]. PLA is aliphatic thermoplastic polyester with linear polymeric chains and undergoes in vivo biodegradability via enzymatic and hydrolytic pathways [239-242] (Figure 2). PLA has excellent mechanical and thermal properties, is biocompatible and biodegradable [243] and has a renewable source [239] which makes it affordable and available for biomedical applications. Lactic acid is a chiral molecule and exists as two 
stereoisometric forms which result in distinct polymers based on morphology such as L-PLA, D-PLA, D,L-PLA and meso-PLA [79]. L-PLA and D-PLA are stereoregular, D,L-PLA is a racemic polymer (mixture of L- and D-lactic acid), and meso-PLA is obtained from D,L-lactide. Crystalline L-PLA that is resistant to hydrolysis [244,245] and amorphous D,L-PLA that is more sensitive to hydrolysis [233] are mostly used for clinical applications [246-248]. In vivo, the Lactic acid that is released by PLLA degradation is converted into glycogen in the liver or incorporated into the tricarboxylic acid cycle and excreted from the lungs as water and carbon dioxide [9].

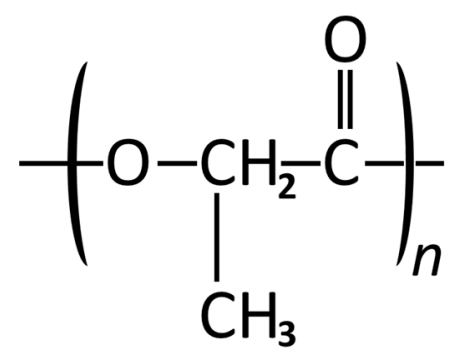

Figure 2. Structural formula of Poly lactic acid.

Scaffolds fabricated for bone tissue engineering applications require specific material properties (porous architecture, adequate porosity levels and mechanical strength) and therefore L-PLA in preferred in the orthopedic applications because it satisfies most of these requirements [74,77,86,87]. Poly (L-lactic acid) (PLLA) has been investigated as a biomaterial and fabricated into scaffolds $[88,249,250]$ by utilizing salt leaching [251], phase separation [252,253], and gas-induced foaming [77,254] methods. These technologies and methods can be used to fabricate porous polymers having porosity below $200 \mu \mathrm{m}$ [79]. However, they do not allow control over porosity in the $200-500 \mu \mathrm{m}$ size range which is imperative for new bone formation and vascular in growth [79]. Precise extrusion manufacturing (PEM) is another method that has been used to produce PLLA scaffold [77]. The scaffold porosity was $\sim 60 \%$ but the effectiveness of adequate porosity distribution resulted in improved mechanical properties ( $\sim 8 \mathrm{MPa}$ compressive strength) [77].

Thermally induced phase separation (TIPS) is another technique that can and has been used successfully to fabricate highly porous scaffolds for bone tissue engineering [79]. This technique utilizes dioxane as a solvent and can be used to create a composite structure having interconnected pores of PLLA with hydroxyapatite (HA). The porosity obtained by this technique can be as high as $95 \%$ with pore sizes ranging from few microns to several hundred microns with also an improvement in the mechanical properties (from $\sim 6 \mathrm{MPa}$ for PLLA alone to $11 \mathrm{MPa}$ for the composite) [79]. This composite skeleton of PLLA/HA when implanted was proven to have good bonding to bone structure $[77,78]$. The compressive strength, porosity levels and distribution and interfacial properties have been improved upon further by using micro and nano sized HA which encourages molecular interactions and formation of chemical linkages between the PLLLA matrix and the inorganic fillers [78,81,255-258]. Cell culture experiments with mesenchymal stem cells (MSCs) revealed that cell affinity and proliferation was improved greatly with the use of these scaffolds [77,79].

PLA synthetic polymers have also been utilized to create a partially degradable bone graft for supporting weak bone in proximal femur [82]. This biomaterials comprises of an outer elastic layer 
of D,L-PLA, HA and calcium carbonate with an inner layer of titanium dip-coated into solutions of PLLA with suspended calcium salts. D,L-PLA owing to its fast degradation rate is strategically placed on the outside to promote biodegradation and replacement with new bone tissue. The PLLA degrades slowly and provides the biocompatible interface between the biological tissues and the inert metallic core of the implant which provides the required mechanical stability [79].

Poly (Lactide-co-glycolide)

Poly lactide-co-glycolide (PLGA) is formed by the combination of lactic and glycolic acid. L- and D,L- both have been utilized for copolymerization and when used in the compositional range of 25\%-75\%, forms amorphous PLGA polymer [79]. 50-50\% PLGA has been shown to be hydrolytically unstable [179,259]. PLGA used in clinical applications has been shown to be biocompatible, non-cytotoxic and non-inflammatory [260,261]. Although PLGA has been extensive used in a variety of clinical applications, its use is limited in the field of orthopedics [262]. The reason for this is probably the hydrophobic nature of PLGA which does not support cell adhesion for promoting bone in-growth [263]. By altering the unit ratio of lactide to glycolide and the molecular weight $\left(M_{\mathrm{w}}\right)$, its biodegradation and mechanical properties can somewhat be controlled [264]. Even with optimization, PLGA is not an ideal candidate to be used for load bearing applications due to the low mechanical strength [79].

PLGA pellets with a lactide to glycolide ratio of 85:15 have been investigated in stimulated body fluid (SBF) to mimic the process of mineralization in teeth and bone in vitro [265]. The pore size of this polymer was in the range of $250-450 \mu \mathrm{m}$ and after 16 days the mineral grown on the surface was a carbonated apatite [265]. Since, this mineral is very close to natural bone tissue it indicates the potential of these biomaterials for bone regeneration applications. Moldable, biodegradable bone graft substitute with PLGA loaded with osteogenic bone morphogenetic protein-2 (BMP-2) microspheres incorporated with calcium phosphate cement (CPC) for bone applications has been investigated [92]. The lactic to glycolic ratio in this polymer/CPC composite was 50:50 and the mechanical strength was very low [266]. Despite lacking adequate mechanical strength, the composite demonstrated good biodegradation rate [92].

Scaffolds constructed with PLGA reinforced with calcium phosphate such as HA as filler improves the mechanical properties compared to scaffold made with PLGA alone. Also, the presence of HA imparts the scaffold with enhanced ability for osteoblast attachment and improved metabolic activity [267-269]. In vitro cultures have also shown that the addition of HA to polymer matrix result in increased mineralization [270] as there is more surface are and roughness for cell attachment and more inorganic material to support bone in-growth [271,272]. Some studies show that the ideal particle size range is 50-300 $\mu \mathrm{m}$ which promotes bone growth [273] whereas, other studies suggest that porous interconnection of the scaffold is more important [274]. With the presence of PLGA, the mechanical properties can be controlled and biomaterials can be prevented from getting too brittle [79]. Three dimensional (3-D) HA/PLGA porous scaffolds have been created using solvent casting and particulate leaching techniques for use in bone replacement applications [275]. Surface grafting of HA by PLGA matrix deposition has shown improvement in the interfacial properties between the polymer and the inorganic CPC in comparison with the non-grafted HA/PLGA [275]. Although both grafted 
and non-grafted biomaterials showed similar potential towards enhancing mineralization, the grafted composite exhibited better bone bonding ability [275].

Poly ( $\varepsilon$-Caprolactone)

Poly( $\varepsilon$-caprolactone) (PCL) is an aliphatic polyester that is a semi-crystalline polyester and can be processed in various forms due to it being highly soluble in a variety of organic solvent [79,276] (Figure 3). PCL is a polymer that has a very high thermal stability when compared with other aliphatic polymers [276,277]. The decomposition temperature (Td) of PCL is $350{ }^{\circ} \mathrm{C}$, while the $\mathrm{Td}$ of aliphatic polyesters is usually between $235^{\circ} \mathrm{C}$ and $255^{\circ} \mathrm{C}$ [278].

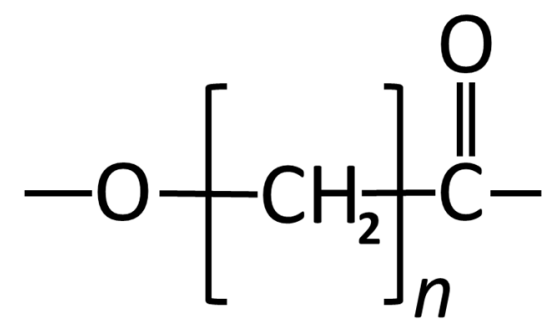

Figure 3. Structural formula of Poly (caprolactone).

PCL has been investigated as a biomaterial for orthopedic application [279,280]. PCL is a biodegradable and biocompatible polymer that has been used for bone repair and treatment of bone defects [97,98]. However, PCL has been shown not to be an ideal biomaterial for these purposes due to its slow degradation rate and inferior mechanical properties [281,282]. Melt blending technique has been used to reinforce PCL with HA [94]. By using this method the polymer is fully melted and the HA particles used as reinforcing fillers are dispersed in the polymeric matrix [94-96]. The particle size used with this technique to fabricate the composites is very important. It was observed that the HA particles with a size range of 3-8 $\mu \mathrm{m}$ imparted higher compressive strengths to the composite materials [94]. Although the addition of fillers improves the compressive strength, increasing the filler content more than a certain level renders these PCL/HA composites too brittle for clinical use [79].

\section{Benzyl Ester of Hyaluronic Acid}

Benzyl esters of hyaluronic acid are also known as HYAFF-11 and they demonstrate good rate of degradation and their degradation products are non-toxic [283]. The degradation time varies from 1-2 weeks to 2-3 months and occurs by hydrolysis via ester bonds. The degradation is dependent on the degree of esterification with the de-esterified HYAFF-11 is more soluble and resembles the precursor hyaluronic acid [284,285]. HYAFF-11 has been investigated for use in bone tissue engineering and vascular graft preparation applications [284,286]. HYAFF-11 has been reinforced with $\alpha$-tricalcium phosphate $(\alpha$-TCP) to form a hydrogel [286]. The compressive strength was seen to improve from $\sim 3 \mathrm{MPa}$ for pure HYAFF-11 to $\sim 17 \mathrm{MPa}$ for the hydrogel. This increased compressive strength value being closer to cancellous bone strength suggests that these HYAFF-11 based hydrogels can be utilized as bioresorbable bone fillers for orthopedic and oral maxillofacial applications. 
Poly-para-dioxanone

Poly-para-dioxanone (PDS) is a polymer consisting of multiple repeating ether-ester units. PDS is obtained by the ring-opening polymerization of para-dioxanone monomer [287,288] (Figure 4). PDS is a polyester used in the field of medicine in form of films, laminates, molded products, foams, adhesives and surface coatings [289,290]. Due to its excellent biocompatibility, biodegradation and flexibility, PDS has been investigated for use in tissue regeneration and fracture repair applications [291-293]. PDS when used for internal fixation of fractures has been shown to be completely biodegradable within the bone tissues [294,295]. PDS can be resorbed completely in vivo within 5-7 months via the alteration of its crystallinity, molecular weight $\mathrm{Mw}$ and the melting temperature [47].

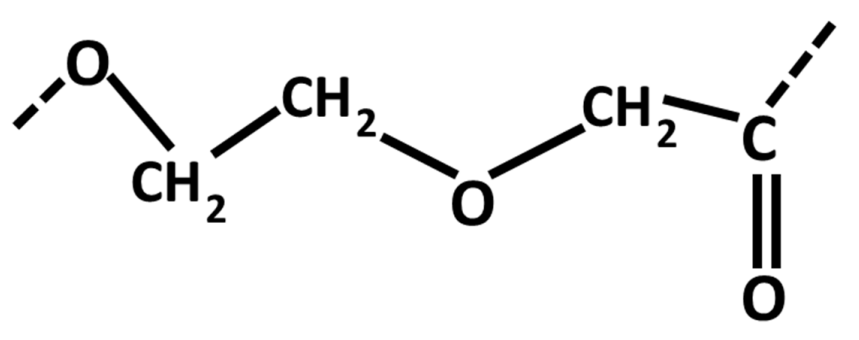

Figure 4. Structural formula of Poly-para-dioxanone.

\subsubsection{Polymer Based Composites}

Polymeric orthopedic prostheses have been fabricated with pure polymers lack adequate mechanical properties required for stress-bearing long bone fracture stabilization [296]. This encouraged research to be carried out towards the development of polymeric composite materials that would possess satisfactory mechanical and biological properties. Completely resorbable polymer composite materials have been used in oral and maxillofacial surgery [297,298]. However, their poor mechanical properties restricted their use and they could not be used for load-bearing applications. Resorbable polymers (polylactide) and its co-polymers such as PLA, PLGA and PLLA degrade when exposed to body fluid [48,50]. Non-resorbable additives such as polyamide fibers have been used in composites to improve material properties by making them partially resorbable [299,300]. The need for second surgery in to remove these non-resorbable fibers lead to the use of completely resorbable and/or bioceramics as reinforcements in the composite materials. HA/PLA, tricalcium phosphate/PLGA and phosphate glass fiber/PLA are some examples of completely resorbable polymeric composites [301-305]. Fibers, coatings and coupling agents can be added to control the rate of degradation. PGF/PLA composites have been developed and the in vitro mechanical and chemical properties have been investigated to develop completely resorbable composites for bone fracture fixation devices [306-309]. The biodegradation rate of various types of polymeric composites has also been studied [310] and bone plates, screws and intramedullary rods have been developed for application to load-bearing long bone fracture fixation and stabilization [303,305,311-315].

\subsection{Bioceramics}

Ceramic biomaterials were initially investigated and used in the field of orthopedic surgery as an alternative to metallic biomaterials. Bioceramics are currently used for bone defect filling, fracture 
repair and stabilization and replacement of diseased bone tissues [316-318]. Ceramic materials are biocompatible, have corrosion resistance and demonstrate tremendous bioactivity. Disadvantages of bioceramics include poor fracture toughness, brittleness and extremely high stiffness [314]. The strength of degradable bioceramics is significantly lower than that of non-resorbable materials [43,317]. Solution-driven and cell-mediated processes are considered to responsible for degradation of bioresorbable ceramics [319]. Lamellar bone replacement occurs after cellular degradation of the ceramic matrix has taken place. The biological behavior of bioceramics is dependent on the physical characteristics and chemical composition [317,320].

\subsubsection{Tricalcium Phosphate}

Tricalcium phosphate (TCP) is a resorbable and bioactive ceramic material (Figure 5a). TCP has two crystalline forms: 1 . $\alpha$-TCP and 2. $\beta$-TCP and the crystallinity and chemical composition resembles closely to that of the mineral phase of bone tissue [44]. TCP demonstrates a higher rate of biodegradation than hydroxyapatite after implantation in vivo [321] which is regulated by a combination of passive dissolution and osteoclast mediated resorption [322]. TCP has been used as synthetic bone defect fillers in dental maxillofacial and orthopedic application $[323,324]$. TCP demonstrates osteoconductivity and active resorption due to its interconnected microporosity which plays a vital role in the graft-bone complex remodeling process [112-114]. Preclinical experiments have shown TCP to almost completely resorb ( $\sim 95 \%)$ after a month and half of implantation in rat tibias with new bone formation and marrow reformation [115]. Similar bone in-growth has been observed for TCP implantation in cancellous bone in canine models [325]. TCP bone replacement grafts have shown to be rapidly infiltrated with bone and slowly resorb by osteoclasts between 6 and 24 months [116].
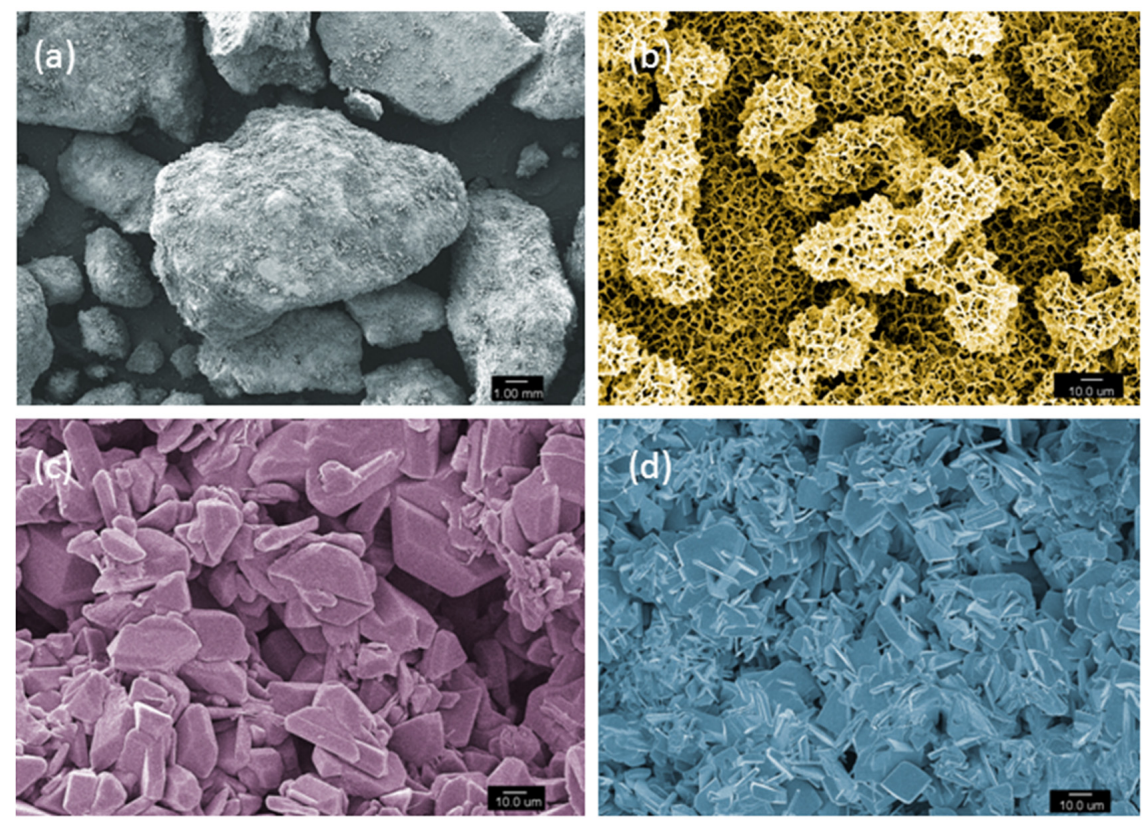

Figure 5. Scanning electron microscope micrographs of (a) $\beta$-Tricalcium phosphate granules; 50× magnification; (b) Hydroxyapatite, 5000× magnification; (c) Dicalcium phosphate dihydrate crystals, $5000 \times$ magnification; (d) Dicalcium phosphate anhydrous crystals, $5000 \times$ magnification. 


\subsubsection{Hydroxyapatite}

Hydroxyapatite (HA) is a bioactive and bioresorbable (variable rate and extent) calcium phosphate that forms the majority of the inorganic component of bone tissue [114,326,327] (Figure 5b). The atomic ratio for calcium to phosphate is 1.67 in HA [44]. Synthetic HA when prepared via a high-temperature reaction is a highly crystalline ceramic. Although synthetic and natural HA differ in terms of physical microstructure, crystal size and porosity, chemical similarities to bone accounts for the osteoconductive potential [114,327]. The bioresorption of HA is slow and heavily related to its properties. Minimal degradation and slow resorption was reported after implantation for 12 weeks in rabbit femoral bone [47]. HA based bioceramics are used for small bone defect filling after tumor resection and/or after bone loss due to fractures in humerus, tibia, calceneus, radius and vertebra [101]. Biphasic ceramic formulation of HA/TCP (60/40) has been shown to provide an intimate scaffold-bone contact, yet has very limited application to be used for load-bearing segmental defects [100].

There have been efforts towards developing HA based bioceramic materials that have been doped with ions. Strontium-HA [102], magnesium-HA [328] and silicon-HA [103] have been tested to improve mechanical and biological properties for bone tissue engineering applications. Although synthetic HA demonstrates good cytocompatibility, its usefulness as a scaffold material is limited due to its moderate to low solubility after implantation [329]. Manganese and zinc doped HA bone substitute materials have been shown to have quicker resorption kinetics [330]. HA has already proven to be an excellent carrier for osteogenic cell populations and osteoconductive growth factors and in future promises to have great utility as a bioactive agent delivery vehicle [104].

\subsubsection{Dicalcium Phosphates}

Dicalcium phosphates (DCPs) are acidic calcium phosphates having an alkaline calcium source, an acidic phosphate source, water as the main constituents. Sometimes other additives are included in the cement composition to alter the setting time and physical properties. Very basic alkaline sources such as calcium oxide [331] and calcium hydroxide [332] can be used to prepare DCP cements. Dicalcium phosphate dehydrate (DCPD), mineral name brushite (Figure 5c), has a calcium to phosphate $(\mathrm{Ca} / \mathrm{P})$ ratio of 1 and hence calcium phosphates with $\mathrm{Ca} / \mathrm{P}$ ratio higher than 1 can be utilized to make brushites $[44,333]$. TCP is the most common basic calcium source in brushite cements $(\mathrm{Ca} / \mathrm{P}$ ratio of 1.5) $[334,335]$. Phosphoric acid is the simplest source of acidic phosphate ions required to prepare DCP cements [334,336]. Since DCP cements have a $\mathrm{Ca} / \mathrm{P}$ ratio of 1 , so acidic calcium phosphate compounds used to prepare DCP cements need to have a $\mathrm{Ca} / \mathrm{P}$ ratio lower than 1 . The only two calcium phosphates with this low ratio are monocalcium phosphate anhydrous (MCPA), also known as monetite and monoclacium phosphate monohydrate (MCPM) [331,337]. MCPM is more commonly used to prepare DCP cements because it has a water molecule that it donates during the cement setting process [44]. DCPD cements can be used as precursors to the anhydrous form that is DCPA or monetite [44,333] (Figure 5d). Monetite can be obtained by dehydration of preset brushite cements or by altering the setting mechanics to favor DCPA formation [44,338,339].

DCP cement based bioceramics are biodegradable. However, brushite cements after implantation start converting to HA which ultimately limits their total resorption and biodegradation rate [44]. This 
phase conversion effect has not been observed with monetite biomaterials and they have a greater amount of new bone formation and infiltration associated with them [333]. Resorbable and injectable brushite cements have been investigated for use in treating metaphyseal bone defects [136,340]. Brushite cements have also been used for treatment of fractures in the tibial plateau [136] and distal metaphysic bone [340].

Leakage and dispersion of cement particles into adjacent tissues has been observed and clinically reported, but since the cements are biodegradable they eventually resorb without any serious complications [340]. Stabilization of osteosynthesis screws is vital in achieving successful stabilization in patients suffering from complicated fractures. Traditionally polymethylmethacrylate (PMMA) cements have been used but they have inherent limitations such as being not strong enough, having exothermic setting reaction and its monomer is cytotoxic [341-344]. For this reason brushite cements have been evaluated and it was found that the pull-out force was increased by 3-fold [131]. Monetite resorbable bioceramics have been evaluated in preclinical and clinical situations for bone augmentation and regeneration in orthopedic and dental applications successfully [125,128,338].

\subsection{Magnesium Based Biodegradable Materials and Alloys}

Elemental magnesium ( $\mathrm{Mg}$ ) was discovered in 1808 and $\mathrm{Mg}$ and its alloys have generated significant interest for use in biomedical applications as implants, osteosynthesis devices, ligatures, and wires for aneurysm treatment and connectors for vessel anastomosis [144,345]. $\mathrm{Mg}^{2+}$ is a cation that is mostly stored in bone tissues and is the fourth most abundant ion in the human body. Mg based metals corrode in aqueous environments via electrochemical reactions that result in the production of $\mathrm{Mg}$ hydroxide and hydrogen gas [144]. The corrosion product of $\mathrm{Mg}\left(\mathrm{Mg}^{2+}\right)$ is easily excreted in urine resulting in the good biological behavior observed when $\mathrm{Mg}$ and its alloys are used for medical applications [144]. Mg based biomaterials have better mechanical properties when compared with other conventional biodegradable materials such as polymers and ceramics [47]. The density of $\mathrm{Mg}$ based metals $\left(1.7-2.0 \mathrm{~g} / \mathrm{cm}^{3}\right)$ matches closely with the density of bone $\left(1.8-2.1 \mathrm{~g} / \mathrm{cm}^{3}\right)$ [47]. Whereas, the densities of other metals (titanium and stainless steel) are much higher or much lower as in case of polymers when compared with natural bone tissue [47]. Also, the elastic modulus of Mg based metals is 45 GPA which is closer to natural bone (Table 1). Titanium alloys and stainless steels used for bone applications have an elastic modulus of $\sim 110 \mathrm{GPa}$ and $\sim 200 \mathrm{GPa}$ respectively [346]. Due to this the stress shielding effect with the use of $\mathrm{Mg}$ metallic materials is reduced significantly.

Based on the distinct advantages of $\mathrm{Mg}$ based metals, they have been extensively investigated both in vitro and in vivo for osteologic repair and regeneration applications. Mostly the focus has been on fabricating screws and plates for fracture fixation and porous scaffold [144]. However, since these have inferior mechanical properties than the conventional metallic non-degradable devices, $\mathrm{Mg}$ based devices are not being used for load bearing application [47,49,347]. Although these Mg based materials possess a superior strength to weight ratio compared to other biodegradable materials, a critical issue is the controllability of the degradation rates [348]. They have a fast degradation rate which induces osteolysis, hemolysis and rapid reduction of mechanical properties [348,349]. In order to control this fast degradation, many surface modifications have been tried with varying success such as micro-arc oxidation [350,351], anodization [352], phosphating [353,354], electro-deposition [355] and biomimetic treatment [356]. 
Binary magnesium-calcium (Mg-Ca) alloys with various levels of calcium contents under different processing conditions have been investigated [357]. Owing to the low density of calcium $\left(1.55 \mathrm{~g} / \mathrm{cm}^{3}\right)$, the $\mathrm{Mg}$-Ca alloys have similar density to bone [358]. The binary $\mathrm{Mg}$-Ca alloys are generally composed of two phases: (i) the $\alpha-\mathrm{Mg}$ and (ii) $\mathrm{Mg}_{2} \mathrm{Ca}$. An increase in the $\alpha-\mathrm{Mg}$ phase in the alloy microstructure leads to higher corrosion rates whereas hot extrusion and hot rolling reduces the corrosion [359]. After implantation of $\mathrm{Mg}-\mathrm{Ca}$ alloy pins in rabbit femoral shafts no cytotoxicity was observed and elevated activity of osteocytes and osteoblasts was shown around the implants indicating good biocompatibility and bioactivity [360].

Zinc ( $\mathrm{Zn})$ is an element that provides a strengthening effect (280 MPa tensile strength) [361,362] and improves corrosion resistance when incorporated into $\mathrm{Mg}$ alloys [361]. Mg alloys with 6\% $\mathrm{Zn}$ have been shown to degrade in vivo with a degradation rate of $2.32 \mathrm{~mm}$ per year and not be cytotoxic to L-929 cells [361]. Other binary Mg alloys with aluminium (Al), Manganese (Mg), Indium (In), Silver (Ag) and Zirconium ( $\mathrm{Zr}$ ) added to their microstructure have been researched upon to evaluate their biological behavior [351]. Further in vivo experimentation and long term implantation studies are required to determine the effect of these elemental inclusions on corrosion resistance, biodegradation and mechanical strength before being applied to clinical applications in the future.

\section{Biocompatibility of Implantable Materials and Their Degradation Products}

To perform successfully, implantable biomaterials must not cause abnormal responses in local tissues and should not produce toxic or carcinogenic effects. Biodegradable materials in particular should serve their intended function while releasing products of degradation that are biocompatible and do not interfere with tissue healing [43]. A major concern associated with using biodegradable materials especially polymers is the possibility of local inflammation due to themselves or via their degradation products [363]. Various polymers have been used successfully for clinical use in the form of sutures, and researchers have theorized that these materials can also be used as fixation devices or replacement implants in orthopaedic and maxillofacial applications [364]. Once implanted, the biodegradation and resorption process begins and are accompanied by a release of acidic by-products which can result in inflammatory reactions [365]. If the capacity of the surrounding tissue to eliminate the by-products is low, due to the poor vascularization or low metabolic activity, the chemical composition of the by-products may lead to local and systemic disturbances [366].

PGA polymers are generally considered to be immunologically inert and not much evidence of infection or symptomatic foreign body reaction exists with their uses as self-reinforced rods [87]. However, in cytological analysis of materials aspirated from malleolar fracture repair effusions developed around PGA implants, inflammatory monocytes have been observed [367-369]. Also, in a series of clinical study of PGA, used for fracture fixation in the foot, foreign body reactions were often reported [369]. In some cases, osteolytic reactions were noted to result from PGA degradation products for 10 weeks following fixation of malleolar fractures [368]. PGA implants have also been shown to induce the activation of the compliment system indicating a localized tissue reaction due to the acidic nature of degradation products [370]. In general, PLA-PGA copolymers demonstrate satisfactory biocompatibility with bone, and absence of significant toxicity, although some reduction in cell proliferation and inflammatory responses has been reported [371]. Biocompatibility and absence 
of infection or inflammation have been observed in studies to promote articular healing in osteochondral defects in the rabbit [372]. Early studies conducted on PLLA implanted in dog femurs have indicated that particles released from these polymers can impede bone formation after 6 weeks by inducing foreign-body inflammatory reactions [373]. However, PLLA-PGA implanted in rabbit skulls has been seen to degrade after 1 year without long-term implications even if inflammation was evident up to 9 months after implantation [374]. After 1 year of implantation, the broken down PLLA is replaced by a comparatively avascular granular fibrous tissue and, after 3 years of implantation, this tissue remains [375]. No inflammatory or foreign body reaction was observed in response to implantation of ultra-high strength L-PLA rods for up to 12 months in the medullary cavity of rabbit femora [376]. When L-PLA was used for a meniscal reconstruction in a dog study, presence of macrophages, fibroblasts, giant cells and lymphocytes were observed [377]. It seems that biocompatibility is compromised once degradation is in full swing and the small particles released promote a foreign body inflammatory reaction, as described in a study where L-PLA was implanted in femoral bones in dogs [378]. Macrophage-like cells and small LPLA particles have also been found in lymph nodes, in a study examining implant materials in the goat femoral diaphysis [379].

The inflammatory response to polymer degradation can be controlled somewhat by the incorporation of basic salts such as sodium bicarbonate, calcium bicarbonate and calcium hydroxyapatite [380]. Also, the incorporation of TCP [381], HA [382] and basic salts [228] into the polymeric matrix results in the production of a hybrid/composite material. These inorganic filler inclusions tailor the degradation and resorption kinetics of the polymer matrix. Such composite materials demonstrate improved biocompatibility and hard tissue integration [383]. In addition, the basic resorption products of HA or TCP buffer the acidic resorption by-products of the aliphatic polyesters and prevent the pH from becoming too low [228,381,382]. More recently, nano-HA incorporated to PLGA scaffolds have been shown to reduce the inflammatory response [384]. Nevertheless, it has been suggested that slow degrading polymers such as PCL induce higher magnitude of angiogenesis when compared to more acidic, faster degrading materials such as PLGA [42]. Conversely, chitosan induces an acute inflammatory response characterized by migration of neutrophils to the implant site which resolves a 12 weeks after implantation. Furthermore, chitosan also induces angiogenesis with minimal chronic inflammation [383]. Gorzelanny et al. have shown that chitosan demonstrates very little inflammatory response upon enzymatic degradation [385].

Calcium phosphate based bioceramics are also widely used for bone regeneration applications. Biodegradable dicalcium phosphates (brushite and monetite) are generally well tolerated by bone and soft tissues and do not cause inflammations in the long-term [386,387]. Following implantation these cements are enclosed in loose connective tissue [388], although they can also be surrounded by fibrous connective tissue if the cement composition is acidic [128]. In vivo studies have shown that early resorption of calcium phosphate cements is regulated by macrophages rather than osteoclasts [389,390]. Similar to in vitro studies implanted cement grafts can resorb via disintegration/fragmentation and rather passive dissolution based upon the solubility constant product of the material [391]. This is critical, since it is known that particles released from calcium phosphate cements can affect osteoblast function, viability, proliferation and production of extracellular matrix adversely [44]. The maximum number of particles that a single osteoblast can support is $\sim 50$, and the smaller the disintegration products are, 
the stronger the negative effect is observed [392].These released particles can also potentially result in peri-implant osteolysis and failure if the micro-environment around the implanted biomaterial is not cleared by extra-cellular media refreshment [393].

\section{Biodegradation of Implanted Materials and Bone Tissue Formation}

The importance of biomaterial degradation (both the rate and extent) cannot be overstated for bone repair and regeneration applications. The degradation capability of biomaterials implanted allows for space to be produced for newly forming bone tissue to not only grow along the implant surface (creeping substitution via osteoconduction) but also to infiltrate within the resorbing cement matrix along with new blood vessels [38]. This infiltration of biomaterial scaffold matrix with blood vessels allows for the bone formation front to progress and be provided with oxygen that is mandatory for survival of the regenerating tissues [394]. It has been observed that some fractured bone tissues can heal within a period of 10-18 months although this varies with the type of bone and function [371]. It is crucial for the biodegradable scaffold to retain its strength during the healing period so as to provide fixation at the fracture site but degrade after the healing as completed. Generally, polymers of the poly( $\alpha$-hydroxy acids) group undergo bulk degradation. Upon placement in aqueous media it has been shown that the molecular weight of the polymer commences to decrease on day one for PGA and PDLA, or after a few weeks for PLLA. However, the mass loss does not start until the molecular chains are reduced to a size which allows them to freely diffuse out of the polymer matrix and similar process occurs after implantation [395]. As seen in Table 1, D,L(PLA) and L(PLA), two biodegradable polymers employed for fracture fixation, degrade after 12-16 months and 24 months respectively. This makes polymers a promising material choice for fracture fixation (provided they have adequate mechanical properties) as far as degradation and healing times are concerned; by the time the fracture heals, the polymers would have degraded completely.

Initial resorption of calcium phosphate cement grafts is affected by the inherent cement properties such as porosity, as well as the site of implantation, which affects the rate of fluid exchange and the properties of the surrounding medium [318,391,396]. The amount of new bone formed is also highly dependent on implantation site and vascular supply, as an adequate blood supply increases the speed of cement resorption and replacement by new woven bone [389]. It is known for serum proteins to be adsorbed onto the cement surface, altering the interfacial properties of the calcium phosphate crystals [397], and favoring in vivo resorption [391]. Research shows that unlike HA cements that undergo negligible resorption over time, dicalcium phosphate cements resorb to a much greater extent in vivo [386,398]. Following implantation, they appear to be rapidly resorbed by simple dissolution and cellular activity [318,399], although the later seems to be the more predominant factor [400]. These cements exhibit an increase in porosity, a decrease in mass and deterioration in mechanical properties [401]. It has been shown that brushite cements experience an initial linear degradation rate of $0.25 \mathrm{~mm}$ per week [402]. This overwhelms the bone formation capacity, resulting in a small bone-material gap and a reduction in the graft mechanical properties [403]. However, after a few weeks implantation the mechanical properties improve, due to bone in-growth into the biomaterial scaffold matrix [44,403]. After the fast degradation of the implanted cements initially, the remaining cement matrix is converted into less soluble apatite via phase transformation and re-precipitation [44]. 
This results in the resorption of the remaining cement to become very slow and limits the extent of degradation and ultimately bone formation and in-growth [404]. After 24 weeks of implantation in an animal model (sheep), brushite cements have been shown to completely convert to poorly crystalline carbonated apatite [405]. At this point there is almost no passive dissolution of the cement that occurs, and resorption is dependent entirely upon osteoclastic activity, rather than macrophage mediated phagocytosis $[389,400]$. The composition of brushite is seen to be stable when stored in distilled water and shows no conversion to apatite [406] also, when stored under alkaline conditions, brushite cements are not converted into apatite unless organic biomolecules (e.g., $10 \mathrm{mM}$ citrate) are added. This indicates that the interfacial energy barrier between the brushite-solution and apatite-solution interfaces in too high to allow spontaneous conversion. However, with the addition of citrate ions, a significant reduction in this energy barrier is observed, and results conversion to HA in vivo [407]. Similar effects have been observed with other polymeric additives such as hyaluronic acid and collagen that slightly decreases the cement resorption rate in vivo [408].

As mentioned earlier, the resorption of cement matrix is an important feature with respect to bone formation at the implanted sites, since it frees up the space needed for new bone formation ideally without compromising mechanical stability. This is the reason that the amount of bone regenerated when using dicalcium phosphate materials is usually higher than that obtained with non-resorbable biomaterials such as HA [125,386,409]. The surfaces of bioceramics such as brushite and monetite have been shown to stimulate osteoblasts activity [410]. Cell culture studies performed on magnesium-doped brushite cements have revealed increased cell proliferation and differentiation [411]. Also, certain polymeric additives, such as collagen, improve cell adhesion to brushite [123], while xanthan gum has a negative effect on the biological response of the cement, resulting in less bone being formed and greater formation of fibrous tissue [408]. The release of growth factors incorporated into cement matrices has also been used to stimulate the bone formation. Vascular endothelial growth factor (VEGF), platelet-derived growth factor (PDGF) and receptor activator of nuclear factor $\mathrm{jB}$ ligand (RANKL) are some of the growth factors that have been assessed to enhance bone regenerative capacity in vivo [44,412]. Bone formation has been observed to be considerably greater with PDGF-loaded brushite-chitosan scaffolds, as well as with the combination PDGF/VEGF [413]. RANKL is a growth factor that promotes osteoclast differentiation and is important towards biodegradation calcium phosphate grafts [414]. Results from studies suggest that the application of growth factors using biodegradable materials could improve the tissue response and promote bone formation in bone regeneration applications [412].

\section{Importance of Physical Properties and Geometrical Considerations of Biodegradable Scaffolds Used for Bone Tissue Engineering}

Various fabrication techniques are applied to process biodegradable materials into 3D polymeric and bioceramics scaffolds with differing geometry affecting physical properties (e.g., porosity and surface area) $[67,220,298,415,416]$. It is imperative that the created 3D scaffold have and maintain sufficient structural integrity during the bone regeneration and remodeling process [417]. Bioceramics are weak under tension and stronger under compression and these facts need to be taken into consideration when fabricating pre-set block grafts for bone tissue engineering applications [418]. Polymers on the other hand provide an opportunity to be prepared into scaffolds with varying geometries, thickness and internal 
configurations. The physical scaffold structure is required to support the polymer/cell/bone tissue construct from the time of implantation up to the point where remodelling occurs by the host tissue. In the case of load-bearing situations, the scaffold matrix is required to serve an additional function by providing sufficient temporary mechanical support to withstand in vivo stresses and physiological loading [43]. Therefore, the biomaterial must be selected and then the scaffold designed with an in vivo degradation rate such that the strength of the scaffold is retained until the tissue engineered transplant is fully remodeled and ultimately assumes its structural role. Also, it is desirable for the mechanical properties of the created scaffold to match that of the host tissue as closely as possible at the time of implantation [380].

It has been noted that under cyclic compressive loading, the polymer matrix of PLGA initially collapses and then stiffens as suggested by the changes in surface deformation and morphology [419]. Another way of designing 3D scaffold constructs are by applying the concept of tensegrity, which evenly distributes and balances mechanical stresses [420,421]. This is achieved by connecting the scaffold framework made up of walls and struts into triangles, pentagons or hexagons, each of which can bear tension or compression. Aligned electrospun collagen fibers have shown to decrease cellular adhesion but a higher cellular proliferation when compared to random fibers [422]. Furthermore, changing the fiber orientation also helps to control the direction of cellular proliferation which can be significantly advantageous when these fibers are used as scaffolds [423]. While it difficult to control the fiber diameter and porosity of electrospun scaffolds at the microscopic level [424], rapid prototyping makes it possible to produce scaffolds with a specific pore and fiber geometry at micro- as well as a macroscopic level [425]. It has been observed that scaffolds produced by rapid prototyping, possessing an average pore size that progressively decreases in the outer layers, have intermediate elastic properties when compared to those possessing a uniform pore-size [426]. It has been seen that decreasing the fiber width and the thickness of layers increases the stiffness of scaffolds [427]. Moreover, producing scaffolds with a higher porosity can decrease the Young modulus [428]. The aforementioned research suggests that scaffolds produced by rapid prototyping can be tailor-made to suit specific implantations sites such as cartilage, tendon and bone which have very different mechanical and physical properties when compared with each other [425].

In order to tissue engineer bone, the creation of a vascularized bed ensures the survival and function of the 3D scaffold/tissue construct by providing nutrition, gas exchange, and elimination of by-products [429]. Since the distance between blood vessels and mesenchymal cells are not larger than $100 \mu \mathrm{m}$ in vivo [430], vascularization of a scaffold may not be achieved by purely relying on capillary ingrowth into the interconnecting pore network from the host tissue. Hence, a porous network structure is necessary in a scaffold to optimize cellular proliferation and nutrient flow. Having an interconnected macropore-structure of 300-500 $\mu \mathrm{m}$ enhances the diffusion rates to and from the center of a scaffold, however, the passage of nutrients and by-products might not occur sufficiently nor efficiently when larger scaffold volumes are employed [298]. The use of pre-vascularization [431], and/or arterio-venous (AV) loops [432], can result in creation of a fluid dynamic microenvironment within the implanted macroporous scaffold that mimics the interstitial fluid conditions present in natural bone [433]. It is also possible to accelerate the rate of vascularization by incorporating angiogenic factors in the degrading matrix of the scaffold [434]. The time frame also has to be taken into account for the capillary system 
to distribute through larger scaffold volume before degradation start and disintegration of the graft material occurs.

The presence of macroporosity in bioceramic scaffolds used for bone repair and regeneration is important in allowing cellular infiltration and proliferation inside the biomaterial [435]. However, increasing the porosity can potentially affects the mechanical properties adversely as mechanical strength of cements is inversely proportional to their porosity. Therefore, the incorporation of macro-pores within the cement structure has to be performed without increasing the overall cement porosity. This can be done by adding porogens, such as mannitol, which create pores having width of $250-500 \mu \mathrm{m}$ in bioceramics scaffolds without reducing the initial compressive strength of the cement [436]. Another way of creating macroporosity in is by using gelatin powder as a template, which produces a closely packed structure with open pores of 100-200 $\mu \mathrm{m}$ [382]. However, the limiting factor of using these techniques is the lack of interconnectivity of the pores created. Better control over pore geometry and distribution can be achieved via computer aided design (CAD) of 3D printed brushite bioceramics $[44,138]$. CAD allows for specific pore designs to be included with varying geometries of the pores incorporated [437].

\section{Conclusions}

The development of biomaterials for bone repair devices and prostheses is a challenge from an engineering and biological perspective. In the field of biomaterials research, degradable materials for bone repair and regeneration are actively sought and generate a lot of interest since their biodegradable nature allows avoiding the second surgery and reduction in the pain and cost for patients. Natural and synthetic polymers and bioceramics are already in clinical use as biodegradable materials and magnesium based metals are a new class of biodegradable materials in development. The mechanical properties, biological behavior and biodegradation mechanism vary for different biomaterials. In comparison with polymers and bioceramics, the tensile strength and stress elongation of magnesium alloys is higher. The highest level brittleness is exhibited by the ceramic materials. From a biological perspective, it has been shown that more new bone is formed around bioceramics and magnesium alloys than around polymers. This can be attributed to the osteoconductive and at times osteoinductive properties the ceramics possess and also the bioactive behavior of magnesium alloys. The acidic degradation products of various polymeric materials can frequently induce inflammatory response which is not observed with the use of bioceramics. Degradation rate and extent is one of the most important characteristics for degradable biomaterials. Bioceramics degrade and show in vivo resorption by cell-mediated and solution-driven processes and demonstrate progressive replacement by lamellar true bone. Biodegradable polymers mostly degrade by enzymolysis and hydrolysis from macromolecules to smaller molecules, and eventually to carbon dioxide and water. The mechanical strength decreases slowly at the initial stage of polymeric degradation, and rapidly during bulk degradation. Metals and alloys that are based on magnesium as their component degrade by corrosion in body fluid with comparatively high degradation rate at the initial stage that becomes progressively slower with time. The mechanical strength of magnesium alloys does not decrease during degradation since their inner structures remain unchanged. Conventional metallic prosthesis constructed using non-degradable materials are fast becoming obsolete due to their inherent disadvantages. As the review indicates, the 
three major kind of biodegradable materials have various advantages and limitations which need to be recognized prior to being selected for the applications they are intended for. Biodegradable and bioactive composite materials are being researched for the creation of high performance implant materials for osteologic repair applications. It is expected that the next generation of biodegradable materials will demonstrate vast improvements in implant and biological tissue interfacing based on the knowledge gained from recent research. However, extensive work is required in order to obtain the ideal bone repair and regeneration biomaterials in the future.

\section{Author Contributions}

Zeeshan Sheikh performed the literature search, wrote the manuscript, compiled the information to create Table 1 and made all figures and illustrations. As the corresponding author, was also responsible for all corrections and revisions needed in the manuscript. Shariq Najeeb performed literature search, compiled the information and helped in the writing of the manuscript. Zohaib Khurshid performed literature search compiled the information and helped in the writing of the manuscript. Vivek Verma performed literature search compiled the information and helped in the writing of the manuscript. Haroon Rashid performed literature search compiled the information and helped in the writing of the manuscript. Michael Glogauer performed literature search, provide the guidelines in order to prepare the manuscript and finalized the manuscript.

\section{Conflicts of Interest}

The authors declare no conflict of interest.

\section{References}

1. Driessens, F.C. Probable phase composition of the mineral in bone. Z. Naturfor. Sect. C 1980, 35, 357-362.

2. Athanasiou, K.A.; Zhu, C.; Lanctot, D.R.; Agrawal, C.M.; Wang, X. Fundamentals of biomechanics in tissue engineering of bone. Tissue Eng. 2000, 6, 361-381. [CrossRef] [PubMed]

3. Driessens, F.C.; van Dijk, J.W.; Borggreven, J.M. Biological calcium phosphates and their role in the physiology of bone and dental tissues I. Composition and solubility of calcium phosphates. Calcif. Tissue Res. 1978, 26, 127-137. [CrossRef] [PubMed]

4. Yaszemski, M.J.; Payne, R.G.; Hayes, W.C.; Langer, R.; Mikos, A.G. Evolution of bone transplantation: Molecular, cellular and tissue strategies to engineer human bone. Biomaterials 1996, 17, 175-185. [CrossRef]

5. Rabie, A.B.; Wong, R.W.; Hagg, U. Composite autogenous bone and demineralized bone matrices used to repair defects in the parietal bone of rabbits. Br. J. Oral Maxillofac. Surg. 2000, 38, 565-570. [CrossRef] [PubMed]

6. Cavalcanti, S.C.; Pereira, C.L.; Mazzonetto, R.; de Moraes, M.; Moreira, R.W. Histological and histomorphometric analyses of calcium phosphate cement in rabbit calvaria. J. Cranio Maxillo Facial Surg. 2008, 36, 354-359. [CrossRef] [PubMed] 
7. Goodrich, J.T.; Sandler, A.L.; Tepper, O. A review of reconstructive materials for use in craniofacial surgery bone fixation materials, bone substitutes, and distractors. Child's Nerv. Syst. 2012, 28, 1577-1588. [CrossRef] [PubMed]

8. Curtis, R.; Goldhahn, J.; Schwyn, R.; Regazzoni, P.; Suhm, N. Fixation principles in metaphyseal bone-A patent based review. Osteoporos. Int. 2005, 16, S54-S64. [CrossRef] [PubMed]

9. Eglin, D.; Alini, M. Degradable polymeric materials for osteosynthesis: Tutorial. Eur. Cell Mater. 2008, 16, 80-91. [PubMed]

10. Christensen, F.B.; Dalstra, M.; Sejling, F.; Overgaard, S.; Bunger, C. Titanium-alloy enhances bone-pedicle screw fixation: Mechanical and histomorphometrical results of titanium-alloy versus stainless steel. Eur. Spine J. 2000, 9, 97-103. [CrossRef] [PubMed]

11. Eppley, B.L.; Sadove, A.M. A comparison of resorbable and metallic fixation in healing of calvarial bone grafts. Plast. Reconstr. Surg. 1995, 96, 316-322. [CrossRef] [PubMed]

12. Marti, C.; Imhoff, A.B.; Bahrs, C.; Romero, J. Metallic versus bioabsorbable interference screw for fixation of bone-patellar tendon-bone autograft in arthroscopic anterior cruciate ligament reconstruction. A preliminary report. Knee Surg. Sports Traumatol. Arthrosc. 1997, 5, 217-221. [CrossRef] [PubMed]

13. Alexander, R.; Theodos, L. Fracture of the bone-grafted mandible secondary to stress shielding: Report of a case and review of the literature. J. Oral Maxillofac. Surg. 1993, 51, 695-697. [CrossRef]

14. Sumner, D.R. Long-term implant fixation and stress-shielding in total hip replacement. $J$. Biomech. 2015, 48, 797-800. [CrossRef] [PubMed]

15. Chanlalit, C.; Shukla, D.R.; Fitzsimmons, J.S.; An, K.N.; O’Driscoll, S.W. Stress shielding around radial head prostheses. J. Hand Surg. 2012, 37, 2118-2125. [CrossRef] [PubMed]

16. Haase, K.; Rouhi, G. Prediction of stress shielding around an orthopedic screw: Using stress and strain energy density as mechanical stimuli. Comput. Biol. Med. 2013, 43, 1748-1757. [CrossRef] [PubMed]

17. Rabie, A.B.; Chay, S.H.; Wong, A.M. Healing of autogenous intramembranous bone in the presence and absence of homologous demineralized intramembranous bone. Am. J. Orthod. Dentofac. Orthop. 2000, 117, 288-297. [CrossRef]

18. Gamradt, S.C.; Lieberman, J.R. Bone graft for revision hip arthroplasty: Biology and future applications. Clin. Orthop. Relat. Res. 2003, 417, 183-194. [PubMed]

19. Urist, M.R. Bone transplants and implants. In Fundamental and Clinical Bone Physiology; MR, U., Ed.; JB Lippincott: Philadelphia, PA, USA, 1980; pp. 331-368.

20. Goldberg, V.M. Selection of bone grafts for revision total hip arthroplasty. Clin. Orthop. Relat. Res. 2000, 381, 68-76. [CrossRef] [PubMed]

21. Shen, F.H.; Samartzis, D.; An, H.S. Cell technologies for spinal fusion. Spine J. 2005, 5, 231S-239S. [CrossRef] [PubMed]

22. Boyne, P.J. Bone induction and the use of HTR polymer as a vehicle for osseous inductor materials. Compendium 1988, 10, S337-S341. [PubMed]

23. Glowacki, J.; Mulliken, J.B. Demineralized bone implants. Clin. Plast. Surg. 1985, 12, 233-241. [PubMed] 
24. Banwart, J.C.; Asher, M.A.; Hassanein, R.S. Iliac crest bone graft harvest donor site morbidity. A statistical evaluation. Spine 1995, 20, 1055-1060. [CrossRef] [PubMed]

25. Ross, N.; Tacconi, L.; Miles, J.B. Heterotopic bone formation causing recurrent donor site pain following iliac crest bone harvesting. Br. J. Neurosurg. 2000, 14, 476-479. [CrossRef] [PubMed]

26. Skaggs, D.L.; Samuelson, M.A.; Hale, J.M.; Kay, R.M.; Tolo, V.T. Complications of posterior iliac crest bone grafting in spine surgery in children. Spine 2000, 25, 2400-2402. [CrossRef] [PubMed]

27. Summers, B.N.; Eisenstein, S.M. Donor site pain from the ilium. A complication of lumbar spine fusion. J. Bone Joint Surg. Br. 1989, 71, 677-680. [PubMed]

28. Buck, B.E.; Malinin, T.I.; Brown, M.D. Bone transplantation and human immunodeficiency virus. An estimate of risk of acquired immunodeficiency syndrome (aids). Clin. Orthop. Relat. Res. 1989, 240, 129-136. [PubMed]

29. Shetty, V.; Han, T.J. Alloplastic materials in reconstructive periodontal surgery. Dent. Clin. N. Am. 1991, 35, 521-530. [PubMed]

30. Sabattini, V.B. Alloplastic implants (HA) for edentulous ridge augmentation before fixed dentures. Longitudinal reevaluation and histology. Prog. Odontoiatr. 1991, 4, 20-28. [PubMed]

31. Schaschke, C.; Audic, J.L. Editorial: Biodegradable materials. Int. J. Mol. Sci. 2014, 15, 21468-21475. [CrossRef] [PubMed]

32. Yeung, K.W.; Wong, K.H. Biodegradable metallic materials for orthopaedic implantations: A review. Technol. Health Care 2012, 20, 345-362.

33. LeGeros, R.Z. Biodegradation and bioresorption of calcium phosphate ceramics. Clin. Mater. 1993, 14, 65-88. [CrossRef]

34. Tevlin, R.; McArdle, A.; Atashroo, D.; Walmsley, G.G.; Senarath-Yapa, K.; Zielins, E.R.; Paik, K.J.; Longaker, M.T.; Wan, D.C. Biomaterials for craniofacial bone engineering. J. Dent. Res. 2014, 93, 1187-1195. [CrossRef] [PubMed]

35. Freed, L.E.; Vunjak-Novakovic, G.; Biron, R.J.; Eagles, D.B.; Lesnoy, D.C.; Barlow, S.K.; Langer, R. Biodegradable polymer scaffolds for tissue engineering. Nat. Biotechnol. 1994, 12, 689-693. [CrossRef]

36. Griffith, L.G.; Naughton, G. Tissue engineering-Current challenges and expanding opportunities. Science 2002, 295, 1009-1014. [CrossRef] [PubMed]

37. Burg, K.J.; Porter, S.; Kellam, J.F. Biomaterial developments for bone tissue engineering. Biomaterials 2000, 21, 2347-2359. [CrossRef]

38. Sheikh, Z.; Sima, C.; Glogauer, M. Bone replacement materials and techniques used for achieving vertical alveolar bone augmentation. Materials 2015, 8, 2953-2993. [CrossRef]

39. Sheikh, Z.; Javaid, M.A.; Hamdan, N.; Hashmi, R. Bone regeneration using bone morphogenetic proteins and various biomaterial carriers. Materials 2015, 8, 1778-1816. [CrossRef]

40. Middleton, J.C.; Tipton, A.J. Synthetic biodegradable polymers as orthopedic devices. Biomaterials 2000, 21, 2335-2346. [CrossRef]

41. Wuisman, P.I.; Smit, T.H. Bioresorbable polymers: Heading for a new generation of spinal cages. Eur. Spine J. 2006, 15, 133-148. [CrossRef] [PubMed] 
42. Hutmacher, D.; Hurzeler, M.B.; Schliephake, H. A review of material properties of biodegradable and bioresorbable polymers and devices for GTR and GBR applications. Int. J. Oral Maxillofac. Implants 1996, 11, 667-678. [PubMed]

43. Ratner, B.D. Biomaterials Science: An introduction to Materials in Medicine. Academic Press: Waltham, MA, USA, 2004.

44. Tamimi, F.; Sheikh, Z.; Barralet, J. Dicalcium phosphate cements: Brushite and monetite. Acta Biomater. 2012, 8, 474-487. [CrossRef] [PubMed]

45. Claes, L.E. Mechanical characterization of biodegradable implants. Clin. Mater. 1992, 10, 41-46. [CrossRef]

46. Blackburn, J.; Hodgskinson, R.; Currey, J.D.; Mason, J.E. Mechanical properties of microcallus in human cancellous bone. J. Orthop. Res. 1992, 10, 237-246. [CrossRef] [PubMed]

47. Tan, L.; Yu, X.; Wan, P.; Yang, K. Biodegradable materials for bone repairs: A review. J. Mater. Sci. Technol. 2013, 29, 503-513. [CrossRef]

48. Armentano, I.; Dottori, M.; Fortunati, E.; Mattioli, S.; Kenny, J. Biodegradable polymer matrix nanocomposites for tissue engineering: A review. Polymer Degrad. Stab. 2010, 95, 2126-2146. [CrossRef]

49. Witte, F.; Hort, N.; Vogt, C.; Cohen, S.; Kainer, K.U.; Willumeit, R.; Feyerabend, F. Degradable biomaterials based on magnesium corrosion. Curr. Opin. Solid State Mater. Sci. 2008, 12, 63-72. [CrossRef]

50. Giannoudis, P.V.; Dinopoulos, H.; Tsiridis, E. Bone substitutes: An update. Injury 2005, 36, S20-S27. [CrossRef] [PubMed]

51. Khoury, F. Augmentation of the sinus floor with mandibular bone block and simultaneous implantation: A 6-year clinical investigation. Int. J. Oral Maxillofac. Implants 1999, 14, 557-564. [PubMed]

52. Block, M.S.; Degen, M. Horizontal ridge augmentation using human mineralized particulate bone: Preliminary results. J. Oral Maxillofac. Surg. 2004, 62, 67-72. [CrossRef] [PubMed]

53. Bolander, M.E.; Balian, G. The use of demineralized bone matrix in the repair of segmental defects. Augmentation with extracted matrix proteins and a comparison with autologous grafts. J. Bone Joint Surg. Am. 1986, 68, 1264-1274. [PubMed]

54. Araujo, P.P.; Oliveira, K.P.; Montenegro, S.C.; Carreiro, A.F.; Silva, J.S.; Germano, A.R. Block allograft for reconstruction of alveolar bone ridge in implantology: A systematic review. Implant Dent. 2013, 22, 304-308. [CrossRef] [PubMed]

55. Sterio, T.W.; Katancik, J.A.; Blanchard, S.B.; Xenoudi, P.; Mealey, B.L. A prospective, multicenter study of bovine pericardium membrane with cancellous particulate allograft for localized alveolar ridge augmentation. Int. J. Periodontics Restor. Dent. 2013, 33, 499-507. [CrossRef] [PubMed]

56. Whittaker, J.M.; James, R.A.; Lozada, J.; Cordova, C.; GaRey, D.J. Histological response and clinical evaluation of heterograft and allograft materials in the elevation of the maxillary sinus for the preparation of endosteal dental implant sites. Simultaneous sinus elevation and root form implantation: An eight-month autopsy report. J. Oral Implantol. 1989, 15, 141-144. [PubMed] 
57. Valentini, P.; Abensur, D. Maxillary sinus floor elevation for implant placement with demineralized freeze-dried bone and bovine bone (bio-oss): A clinical study of 20 patients. Int. J. Periodontics Restor. Dent. 1997, 17, 232-241.

58. Guerrero, J.S.; al-Jandan, B.A. Allograft for maxillary sinus floor augmentation: A retrospective study of 90 cases. Implant Dent. 2012, 21, 136-140. [CrossRef] [PubMed]

59. Avila, G.; Neiva, R.; Misch, C.E.; Galindo-Moreno, P.; Benavides, E.; Rudek, I.; Wang, H.L. Clinical and histologic outcomes after the use of a novel allograft for maxillary sinus augmentation: A case series. Implant Dent. 2010, 19, 330-341. [CrossRef] [PubMed]

60. Sohn, D.S.; Lee, J.K.; An, K.M.; Shin, H.I. Histomorphometric evaluation of mineralized cancellous allograft in the maxillary sinus augmentation: A 4 case report. Implant Dent. 2009, 18, 172-181. [CrossRef] [PubMed]

61. Jo, J.Y.; Jeong, S.I.; Shin, Y.M.; Kang, S.S.; Kim, S.E.; Jeong, C.M.; Huh, J.B. Sequential delivery of BMP-2 and BMP-7 for bone regeneration using a heparinized collagen membrane. Int. J. Oral Maxillofac. Surg. 2015, 4, 921-928. [CrossRef] [PubMed]

62. Cha, J.K.; Lee, J.S.; Kim, M.S.; Choi, S.H.; Cho, K.S.; Jung, U.W. Sinus augmentation using BMP-2 in a bovine hydroxyapatite/collagen carrier in dogs. J. Clin. Periodontol. 2014, 41, 86-93. [CrossRef] [PubMed]

63. Geiger, M.; Li, R.; Friess, W. Collagen sponges for bone regeneration with rhbmp-2. Adv. Drug Deliv. Rev. 2003, 55, 1613-1629. [CrossRef] [PubMed]

64. John, A.; Hong, L.; Ikada, Y.; Tabata, Y. A trial to prepare biodegradable collagen-hydroxyapatite composites for bone repair. J. Biomater. Sci. Polymer Ed. 2001, 12, 689-705. [CrossRef]

65. Chung, K.M.; Salkin, L.M.; Stein, M.D.; Freedman, A.L. Clinical evaluation of a biodegradable collagen membrane in guided tissue regeneration. J. Periodontol. 1990, 61, 732-736. [CrossRef] [PubMed]

66. Matilinna, K.P., Ed.; Barrier membranes for tissue regeneration and bone augmentation techniques in dentistry. In Handbook of Oral Biomaterials; Matilinna, K.P., Ed.; Pan Stanford Publishing: Singapore, Singapore, 2014.

67. Liu, X.; Ma, P.X. Polymeric scaffolds for bone tissue engineering. Ann. Biomed. Eng. 2004, 32 , 477-486. [CrossRef] [PubMed]

68. Silva, G.; Ducheyne, P.; Reis, R. Materials in particulate form for tissue engineering. 1. Basic concepts. J. Tissue Eng. Regen. Med. 2007, 1, 4-24. [CrossRef] [PubMed]

69. Lee, J.Y.; Kim, K.H.; Shin, S.Y.; Rhyu, I.C.; Lee, Y.M.; Park, Y.J.; Chung, C.P.; Lee, S.J. Enhanced bone formation by transforming growth factor- $\beta 1$-releasing collagen/chitosan microgranules. J. Biomed. Mater. Res. A 2006, 76, 530-539. [CrossRef] [PubMed]

70. Zhao, H.; Ma, L.; Gao, C.; Shen, J. Fabrication and properties of mineralized collagen-chitosan/hydroxyapatite scaffolds. Polym. Adv. Technol. 2008, 19, 1590-1596. [CrossRef]

71. Lee, E.J.; Jun, S.H.; Kim, H.E.; Kim, H.W.; Koh, Y.H.; Jang, J.H. Silica xerogel-chitosan nano-hybrids for use as drug eluting bone replacement. J. Mater. Sci. Mater. Med. 2010, 21, 207-214. [CrossRef] [PubMed] 
72. Ambrose, C.G.; Hartline, B.E.; Clanton, T.O.; Lowe, W.R.; McGarvey, W.C. Polymers in orthopaedic surgery. In Advanced Polymers in Medicine; Springer: Berlin, Germany; Heidelberg, Germany, 2015; pp. 129-145.

73. Törmälä, P. Biodegradable self-reinforced composite materials; manufacturing structure and mechanical properties. Clin. Mater. 1992, 10, 29-34. [CrossRef] [PubMed]

74. Christel, P.; Chabot, F.; Leray, J.; Morin, C.; Vert, M. Biodegradable composites for internal fixation. Biomaterials 1980, 1, 1-16.

75. Linhart, W.; Peters, F.; Lehmann, W.; Schwarz, K.; Schilling, A.F.; Amling, M.; Rueger, J.M.; Epple, M. Biologically and chemically optimized composites of carbonated apatite and polyglycolide as bone substitution materials. J. Biomed. Mater. Res. 2001, 54, 162-171. [CrossRef]

76. Niu, X.; Feng, Q.; Wang, M.; Guo, X.; Zheng, Q. Porous nano-HA/collagen/PLLA scaffold containing chitosan microspheres for controlled delivery of synthetic peptide derived from BMP-2. J. Controll. Release 2009, 134, 111-117. [CrossRef] [PubMed]

77. Xiong, Z.; Yan, Y.; Zhang, R.; Sun, L. Fabrication of porous poly (L-lactic acid) scaffolds for bone tissue engineering via precise extrusion. Scr. Mater. 2001, 45, 773-779. [CrossRef]

78. Higashi, S.; Yamamuro, T.; Nakamura, T.; Ikada, Y.; Hyon, S.-H.; Jamshidi, K. Polymer-hydroxyapatite composites for biodegradable bone fillers. Biomaterials 1986, 7 , 183-187. [CrossRef]

79. Razak, S.I.A.; Sharif, N.; Rahman, W. Biodegradable polymers and their bone applications: A review. Int. J. Basic Appl. Sci. 2012, 12, 31-49.

80. Vert, M. Aliphatic polyesters: Great degradable polymers that cannot do everything. Biomacromolecules 2005, 6, 538-546. [CrossRef] [PubMed]

81. Nejati, E.; Mirzadeh, H.; Zandi, M. Synthesis and characterization of nano-hydroxyapatite rods/poly (L-lactide acid) composite scaffolds for bone tissue engineering. Compos. A 2008, 39, 1589-1596. [CrossRef]

82. Lagoa, A.L.; Wedemeyer, C.; von Knoch, M.; Löer, F.; Epple, M. A strut graft substitute consisting of a metal core and a polymer surface. J. Mater. Sci. 2008, 19, 417-424. [CrossRef] [PubMed]

83. Warden, W.H.; Friedman, R.; Teresi, L.M.; Jackson, D.W. Magnetic resonance imaging of bioabsorbable polylactic acid interference screws during the first 2 years after anterior cruciate ligament reconstruction. Arthroscopy 1999, 15, 474-480. [CrossRef] [PubMed]

84. Bozic, K.J.; Perez, L.E.; Wilson, D.R.; Fitzgibbons, P.G.; Jupiter, J.B. Mechanical testing of bioresorbable implants for use in metacarpal fracture fixation. J. Hand Surg. 2001, 26, 755-761. [CrossRef] [PubMed]

85. Ignatius, A.; Claes, L.E. In vitro biocompatibility of bioresorbable polymers: Poly (L, DL-lactide) and poly (L-lactide-co-glycolide). Biomaterials 1996, 17, 831-839. [CrossRef]

86. Leenslag, J.W.; Pennings, A.J.; Bos, R.R.; Rozema, F.R.; Boering, G. Resorbable materials of poly (L-lactide): VII. In vivo and in vitro degradation. Biomaterials 1987, 8, 311-314. [CrossRef]

87. Vainionpää, S.; Kilpikari, J.; Laiho, J.; Helevirta, P.; Rokkanen, P.; Törmälä, P. Strength and strength retention vitro, of absorbable, self-reinforced polyglycolide (PGA) rods for fracture fixation. Biomaterials 1987, 8, 46-48. [CrossRef] 
88. Nam, Y.S.; Park, T.G. Porous biodegradable polymeric scaffolds prepared by thermally induced phase separation. J. Biomed. Mater. Res. 1999, 47, 8-17. [CrossRef]

89. Nie, L.; Chen, D.; Fu, J.; Yang, S.; Hou, R.; Suo, J. Macroporous biphasic calcium phosphate scaffolds reinforced by poly-L-lactic acid/hydroxyapatite nanocomposite coatings for bone regeneration. Biochem. Eng. J. 2015, 98, 29-37. [CrossRef]

90. Ji, Y.; Xu, G.P.; Zhang, Z.P.; Xia, J.J.; Yan, J.L.; Pan, S.H. BMP-2/PLGA delayed-release microspheres composite graft, selection of bone particulate diameters, and prevention of aseptic inflammation for bone tissue engineering. Ann. Biomed. Eng. 2010, 38, 632-639. [CrossRef] [PubMed]

91. Gavenis, K.; Schneider, U.; Groll, J.; Schmidt-Rohlfing, B. Bmp-7-loaded PGLA microspheres as a new delivery system for the cultivation of human chondrocytes in a collagen type I gel: The common nude mouse model. Int. J. Artif. Organs 2010, 33, 45-53. [PubMed]

92. Fei, Z.; Hu, Y.; Wu, D.; Wu, H.; Lu, R.; Bai, J.; Song, H. Preparation and property of a novel bone graft composite consisting of rhbmp-2 loaded PLGA microspheres and calcium phosphate cement. J. Mater. Sci. 2008, 19, 1109-1116. [CrossRef] [PubMed]

93. Sheikh, F.A.; Ju, H.W.; Moon, B.M.; Lee, O.J.; Kim, J.H.; Park, H.J.; Kim, D.W.; Kim, D.K.; Jang, J.E.; Khang, G. Hybrid scaffolds based on PLGA and silk for bone tissue engineering. $J$. Tissue Eng. Regen. Med. 2015. [CrossRef] [PubMed]

94. Chen, B.; Sun, K. Poly ( $\varepsilon$-caprolactone)/hydroxyapatite composites: Effects of particle size, molecular weight distribution and irradiation on interfacial interaction and properties. Polymer Test. 2005, 24, 64-70. [CrossRef]

95. Wiria, F.; Leong, K.; Chua, C.; Liu, Y. Poly- $\varepsilon$-caprolactone/hydroxyapatite for tissue engineering scaffold fabrication via selective laser sintering. Acta Biomater. 2007, 3, 1-12. [CrossRef] [PubMed]

96. Yu, H.; Matthew, H.W.; Wooley, P.H.; Yang, S.Y. Effect of porosity and pore size on microstructures and mechanical properties of poly- $\varepsilon$-caprolactone-hydroxyapatite composites. J. Biomed. Mater. Res. Part B 2008, 86, 541-547. [CrossRef] [PubMed]

97. Porter, J.R.; Henson, A.; Popat, K.C. Biodegradable poly ( $\varepsilon$-caprolactone) nanowires for bone tissue engineering applications. Biomaterials 2009, 30, 780-788. [CrossRef] [PubMed]

98. Pitt, G.; Gratzl, M.; Kimmel, G.; Surles, J.; Sohindler, A. Aliphatic polyesters II. The degradation of poly (D,L-lactide), poly ( $\varepsilon$-caprolactone), and their copolymers in vivo. Biomaterials 1981, 2 , 215-220. [CrossRef]

99. Prosecká, E.; Rampichová, M.; Litvinec, A.; Tonar, Z.; Králíčková, M.; Vojtová, L.; Kochová, P.; Plencner, M.; Buzgo, M.; Míčková, A. Collagen/hydroxyapatite scaffold enriched with polycaprolactone nanofibers, thrombocyte-rich solution and mesenchymal stem cells promotes regeneration in large bone defect in vivo. J. Biomed. Mater. Res. A 2015, 103, 671-682. [CrossRef] [PubMed]

100. Balçik, C.; Tokdemir, T.; Şenköylü, A.; Koç, N.; Timuçin, M.; Akin, S.; Korkusuz, P.; Korkusuz, F. Early weight bearing of porous HA/TCP (60/40) ceramics in vivo: A longitudinal study in a segmental bone defect model of rabbit. Acta Biomater. 2007, 3, 985-996. [CrossRef] [PubMed] 
101. Quarto, R.; Mastrogiacomo, M.; Cancedda, R.; Kutepov, S.M.; Mukhachev, V.; Lavroukov, A.; Kon, E.; Marcacci, M. Repair of large bone defects with the use of autologous bone marrow stromal cells. N. Engl. J. Med. 2001, 344, 385-386. [CrossRef] [PubMed]

102. Mardziah, C.; Sopyan, I.; Ramesh, S. Strontium-doped hydroxyapatite nanopowder via sol-gel method: Effect of strontium concentration and calcination temperature on phase behavior. Trends Biomater. Artif. Organs 2009, 23, 105-113.

103. Thian, E.; Huang, J.; Best, S.; Barber, Z.; Bonfield, W. Novel silicon-doped hydroxyapatite (Si-HA) for biomedical coatings: An in vitro study using acellular simulated body fluid. $J$. Biomed. Mater. Res. Part B 2006, 76, 326-333. [CrossRef] [PubMed]

104. Noshi, T.; Yoshikawa, T.; Ikeuchi, M.; Dohi, Y.; Ohgushi, H.; Horiuchi, K.; Sugimura, M.; Ichijima, K.; Yonemasu, K. Enhancement of the in vivo osteogenic potential of marrow/hydroxyapatite composites by bovine bone morphogenetic protein. J. Biomed. Mater. Res. 2000, 52, 621-630. [CrossRef]

105. Oonishi, H. Orthopaedic applications of hydroxyapatite. Biomaterials 1991, 12, 171-178. [CrossRef]

106. Cook, S.D.; Thomas, K.A.; Kay, J.F.; Jarcho, M. Hydroxyapatite-coated titanium for orthopedic implant applications. Clin. Orthop. Relat. Res. 1988, 232, 225-243. [CrossRef] [PubMed]

107. Sopyan, I.; Mel, M.; Ramesh, S.; Khalid, K. Porous hydroxyapatite for artificial bone applications. Sci. Technol. Adv. Mater. 2007, 8, 116-123. [CrossRef]

108. Heise, U.; Osborn, J.; Duwe, F. Hydroxyapatite ceramic as a bone substitute. Int. Orthop. 1990, 14, 329-338. [CrossRef] [PubMed]

109. Kumar, A.; Biswas, K.; Basu, B. Hydroxyapatite-titanium bulk composites for bone tissue engineering applications. J. Biomed. Mater. Res. Part A 2015, 103, 791-806. [CrossRef] [PubMed]

110. Dumic-Cule, I.; Pecina, M.; Jelic, M.; Jankolija, M.; Popek, I.; Grgurevic, L.; Vukicevic, S. Biological aspects of segmental bone defects management. Int. Orthop. 2015, 39, 1005-1011. [CrossRef] [PubMed]

111. Singh, A.B.; Majumdar, S. The composite of hydroxyapatite with collagen as a bone grafting material. J. Adv. Med. Dent. Sci. Res. 2014, 2, 53-55.

112. Hing, K.A.; Wilson, L.F.; Buckland, T. Comparative performance of three ceramic bone graft substitutes. Spine J. 2007, 7, 475-490. [CrossRef] [PubMed]

113. Nandi, S.K.; Ghosh, S.K.; Kundu, B.; De, D.K.; Basu, D. Evaluation of new porous $\beta$-tri-calcium phosphate ceramic as bone substitute in goat model. Small Rumin. Res. 2008, 75, 144-153. [CrossRef]

114. Ghosh, S.K.; Nandi, S.K.; Kundu, B.; Datta, S.; De, D.K.; Roy, S.K.; Basu, D. In vivo response of porous hydroxyapatite and $\beta$-tricalcium phosphate prepared by aqueous solution combustion method and comparison with bioglass scaffolds. J. Biomed. Mater. Res. B 2008, 86, 217-227. [CrossRef] [PubMed]

115. Cutright, D.E.; Bhaskar, S.N.; Brady, J.M.; Getter, L.; Posey, W.R. Reaction of bone to tricalcium phosphate ceramic pellets. Oral Surg. Oral Med. Oral Pathol. 1972, 33, 850-856. [CrossRef] 
116. Bohner, M. Physical and chemical aspects of calcium phosphates used in spinal surgery. Eur. Spine J. 2001, 10, S114-S121. [PubMed]

117. Peter, S.J.; Kim, P.; Yasko, A.W.; Yaszemski, M.J.; Mikos, A.G. Crosslinking Characteristics of an Injectable Poly (Propylene Fumarate)/ $\beta$-tricalcium Phosphate Paste and Mechanical Properties of the Crosslinked Composite for Use as a Biodegradable Bone Cement; Cambridge University Press: Cambridge, UK, 1998.

118. Miranda, P.; Saiz, E.; Gryn, K.; Tomsia, A.P. Sintering and robocasting of $\beta$-tricalcium phosphate scaffolds for orthopaedic applications. Acta Biomater. 2006, 2, 457-466. [CrossRef] [PubMed]

119. Galois, L.; Mainard, D.; Delagoutte, J. Beta-tricalcium phosphate ceramic as a bone substitute in orthopaedic surgery. Int. Orthop. 2002, 26, 109-115. [PubMed]

120. Zhang, X.; Meng, S.; Huang, Y.; Xu, M.; He, Y.; Lin, H.; Han, J.; Chai, Y.; Wei, Y.; Deng, X. Electrospun gelatin/ $\beta$-TCP composite nanofibers enhance osteogenic differentiation of BMSCs and in vivo bone formation by activating $\mathrm{Ca}^{2+}$. Stem Cells Int. 2015. [CrossRef]

121. Liu, B.; Lun, D.X. Current application of $\beta$-tricalcium phosphate composites in orthopaedics. Orthop. Surg. 2012, 4, 139-144. [CrossRef] [PubMed]

122. Shadanbaz, S.; Dias, G.J. Calcium phosphate coatings on magnesium alloys for biomedical applications: A review. Acta Biomater. 2012, 8, 20-30. [CrossRef] [PubMed]

123. Tamimi, F.; Kumarasami, B.; Doillon, C.; Gbureck, U.; le Nihouannen, D.; Cabarcos, E.L.; Barralet, J.E. Brushite-collagen composites for bone regeneration. Acta Biomater. 2008, 4, 1315-1321. [CrossRef] [PubMed]

124. Tamimi, F.; Torres, J.; al-Abedalla, K.; Lopez-Cabarcos, E.; Alkhraisat, M.H.; Bassett, D.C.; Gbureck, U.; Barralet, J.E. Osseointegration of dental implants in 3D-printed synthetic onlay grafts customized according to bone metabolic activity in recipient site. Biomaterials 2014, 35, 5436-5445. [CrossRef] [PubMed]

125. Tamimi, F.; Torres, J.; Bassett, D.; Barralet, J.; Cabarcos, E.L. Resorption of monetite granules in alveolar bone defects in human patients. Biomaterials 2010, 31, 2762-2769. [CrossRef] [PubMed]

126. Tamimi, F.; Torres, J.; Bettini, R.; Ruggera, F.; Rueda, C.; Lopez-Ponce, M.; Lopez-Cabarcos, E. Doxycycline sustained release from brushite cements for the treatment of periodontal diseases. J. Biomed. Mater. Res. A 2008, 85, 707-714. [CrossRef] [PubMed]

127. Tamimi, F.; Torres, J.; Gbureck, U.; Lopez-Cabarcos, E.; Bassett, D.C.; Alkhraisat, M.H.; Barralet, J.E. Craniofacial vertical bone augmentation: A comparison between 3D printed monolithic monetite blocks and autologous onlay grafts in the rabbit. Biomaterials 2009, 30, 6318-6326. [CrossRef] [PubMed]

128. Tamimi, F.; Torres, J.; Lopez-Cabarcos, E.; Bassett, D.C.; Habibovic, P.; Luceron, E.; Barralet, J.E. Minimally invasive maxillofacial vertical bone augmentation using brushite based cements. Biomaterials 2009, 30, 208-216. [CrossRef] [PubMed]

129. Tamura, K.; Sato, S.; Kishida, M.; Asano, S.; Murai, M.; Ito, K. The use of porous beta-tricalcium phosphate blocks with platelet-rich plasma as an onlay bone graft biomaterial. J. Periodontol. 2007, 78, 315-321. [CrossRef] [PubMed] 
130. Marinno, F.T.; Torres, J.; Tresguerres, I.; Jerez, L.B.; Cabarcos, E.L. Vertical bone augmentation with granulated brushite cement set in glycolic acid. J. Biomed. Mater. Res. A 2007, 81, 93-102. [CrossRef] [PubMed]

131. Van Landuyt, P.; Peter, B.; Beluze, L.; Lemaitre, J. Reinforcement of osteosynthesis screws with brushite cement. Bone 1999, 25, 95S-98S. [CrossRef]

132. Gehrke SA, F.G. Buccal dehiscence and sinus lift cases-Predictable bone augmentation with synthetic bone material. Implants 2010, 11, 1-14.

133. Paxton, J.Z.; Donnelly, K.; Keatch, R.P.; Baar, K.; Grover, L.M. Factors affecting the longevity and strength in an in vitro model of the bone-ligament interface. Ann. Biomed. Eng. 2010, 38, 2155-2166. [CrossRef] [PubMed]

134. Paxton, J.Z.; Grover, L.M.; Baar, K. Engineering an in vitro model of a functional ligament from bone to bone. Tissue Eng. Part A 2010, 16, 3515-3525. [CrossRef] [PubMed]

135. Mehrban, N.; Paxton, J.Z.; Bowen, J.; Bolarinwa, A.; Vorndran, E.; Gbureck, U.; Grover, L.M. Comparing physicochemical properties of printed and hand cast biocements designed for ligament replacement. Adv. Appl. Ceram. 2011, 110, 162-167. [CrossRef]

136. Theiss, F.; Apelt, D.; Brand, B.; Kutter, A.; Zlinszky, K.; Bohner, M.; Matter, S.; Frei, C.; Auer, J.A.; von Rechenberg, B. Biocompatibility and resorption of a brushite calcium phosphate cement. Biomaterials 2005, 26, 4383-4394. [CrossRef] [PubMed]

137. Zhou, H.; Luchini, T.J.; Agarwal, A.K.; Goel, V.K.; Bhaduri, S.B. Development of monetite-nanosilica bone cement: A preliminary study. J. Biomed. Mater. Res. Part B 2014, 102, 1620-1626. [CrossRef] [PubMed]

138. Saska, S.; Mendes, L.S.; Gaspar, A.M.M.; de Oliveira Capote, T.S. Bone substitute materials in implant dentistry. Implant Dent. 2015, 2, 158-167.

139. Hughes, E.; Yanni, T.; Jamshidi, P.; Grover, L. Inorganic cements for biomedical application: Calcium phosphate, calcium sulphate and calcium silicate. Adv. Appl. Ceram. 2015, 114, 65-76. [CrossRef]

140. Mestres, G.; Santos, C.F.; Engman, L.; Persson, C.; Ott, M.K. Scavenging effect of trolox released from brushite cements. Acta Biomater. 2015, 11, 459-466. [CrossRef] [PubMed]

141. Rodriguez, L.C.; Chari, J.; Aghyarian, S.; Gindri, I.M.; Kosmopoulos, V.; Rodrigues, D.C. Preparation and characterization of injectable brushite filled-poly (methyl methacrylate) bone cement. Materials 2014, 7, 6779-6795. [CrossRef]

142. Zhang, S.; Wan, W.; Xu, K.; Yuan, Q.; Xing, M. Dual-functional biomaterials for bone regeneration and infection control. J. Biomater. Tissue Eng. 2014, 4, 875-885. [CrossRef]

143. Moseley, J.P.; Carroll, M.E.; Mccanless, J.D. Composite Bone Graft Substitute Cement and Articles Produced Therefrom. U.S. Patent 7,754,246, 13 July 2010.

144. Staiger, M.P.; Pietak, A.M.; Huadmai, J.; Dias, G. Magnesium and its alloys as orthopedic biomaterials: A review. Biomaterials 2006, 27, 1728-1734. [CrossRef] [PubMed]

145. Wong, H.M.; Yeung, K.W.; Lam, K.O.; Tam, V.; Chu, P.K.; Luk, K.D.; Cheung, K.M. A biodegradable polymer-based coating to control the performance of magnesium alloy orthopaedic implants. Biomaterials 2010, 31, 2084-2096. [CrossRef] [PubMed] 
146. Zeng, R.; Dietzel, W.; Witte, F.; Hort, N.; Blawert, C. Progress and challenge for magnesium alloys as biomaterials. Adv. Eng. Mater. 2008, 10, B3-B14. [CrossRef]

147. Waizy, H.; Seitz, J.-M.; Reifenrath, J.; Weizbauer, A.; Bach, F.-W.; Meyer-Lindenberg, A.; Denkena, B.; Windhagen, H. Biodegradable magnesium implants for orthopedic applications. J. Mater. Sci. 2013, 48, 39-50. [CrossRef]

148. Gu, X.-N.; Zheng, Y.-F. A review on magnesium alloys as biodegradable materials. Front. Mater. Sci. China 2010, 4, 111-115. [CrossRef]

149. Witte, F. The history of biodegradable magnesium implants: A review. Acta Biomater. 2010, 6, 1680-1692. [CrossRef] [PubMed]

150. Liu, C.; Wan, P.; Tan, L.L.; Wang, K.; Yang, K. Preclinical investigation of an innovative magnesium-based bone graft substitute for potential orthopaedic applications. J. Orthop. Transl. 2014, 2, 139-148. [CrossRef]

151. Lyndon, J.A.; Boyd, B.J.; Birbilis, N. Metallic implant drug/device combinations for controlled drug release in orthopaedic applications. J. Controll. Release 2014, 179, 63-75. [CrossRef] [PubMed]

152. Chaya, A.; Yoshizawa, S.; Verdelis, K.; Myers, N.; Costello, B.J.; Chou, D.-T.; Pal, S.; Maiti, S.; Kumta, P.N.; Sfeir, C. In vivo study of magnesium plate and screw degradation and bone fracture healing. Acta Biomater. 2015, 18, 262-269. [CrossRef] [PubMed]

153. Jiang, G.; Li, Q.; Wang, C.; Dong, J.; He, G. Fabrication of graded porous titanium-magnesium composite for load-bearing biomedical applications. Mater. Des. 2015, 67, 354-359. [CrossRef]

154. Wong, S.-S. Investigation on Mg-Mn-Zn Alloys as Potential Biodegradable Materials for Orthopaedic Applications; The University of Hong Kong: Pokfulam, Hong Kong, 2015.

155. Chaya, A.; Yoshizawa, S.; Verdelis, K.; Noorani, S.; Costello, B.J.; Sfeir, C. Fracture healing using degradable magnesium fixation plates and screws. J. Oral Maxil. Surg. 2015, 73, 295-305. [CrossRef] [PubMed]

156. Zhou, J.; Huang, W.; Li, Q.; She, Z.; Chen, F.; Li, L. A novel multilayer model with controllable mechanical properties for magnesium-based bone plates. J. Mater. Sci. 2015, 26, 1-11. [CrossRef] [PubMed]

157. Khakbaz, H.; Walter, R.; Gordon, T.; Kannan, M.B. Self-dissolution assisted coating on magnesium metal for biodegradable bone fixation devices. Mater. Res. Express 2014, 1. [CrossRef]

158. Tang, J.; Wang, J.; Xie, X.; Zhang, P.; Lai, Y.; Li, Y.; Qin, L. Surface coating reduces degradation rate of magnesium alloy developed for orthopaedic applications. J. Orthop. Transl. 2013, 1, 41-48. [CrossRef]

159. Van der Stok, J.; Koolen, M.; de Maat, M.; Yavari, S.A.; Alblas, J.; Patka, P.; Verhaar, J.; van Lieshout, E.; Zadpoor, A.; Weinans, H. Full regeneration of segmental bone defects using porous titanium implants loaded with BMP-2 containing fibrin gels. Eur. Cells Mater. 2015, 29, 141.

160. Mikos, A.G.; Wong, M.E.; Young, S.W.; Kretlow, J.D.; Shi, M.; Kasper, K.F.; Spicer, P. Combined Space Maintenance and Bone Regeneration System for the Reconstruction of Large Osseous Defects. US Patent 20,150,081,034, 19 September 2014. 
161. Tomlinson, A.; Comerford, E.; Birch, R.; Innes, J.; Walton, M. Mechanical performance in axial compression of a titanium polyaxial locking plate system in a fracture gap model. Vet. Comp. Orthop. Traumatol. 2015, 28, 88-94. [CrossRef] [PubMed]

162. Al-Moraissi, E.A.M.; Ellis, E. Biodegradable and titanium osteosynthesis provide similar stability for orthognathic surgery. J. Oral. Maxil. Surg. 2015, 73, 1795-1808. [CrossRef] [PubMed]

163. Kang, I.G.; Jung, J.H.; Kim, S.T.; Choi, J.Y.; Sykes, J.M. Comparison of titanium and biodegradable plates for treating midfacial fractures. J. Oral. Maxil. Surg. 2014, 72, 761-762. [CrossRef] [PubMed]

164. Mazzoni, S.; Bianchi, A.; Schiariti, G.; Badiali, G.; Marchetti, C. Cad-cam cutting guides and customized titanium plates useful in upper maxilla waferless repositioning. J. Oral. Maxillofac. Surg. 201 2015, 73, 701-707. [CrossRef] [PubMed]

165. Paeng, J.-Y.; Hong, J.; Kim, C.-S.; Kim, M.-J. Comparative study of skeletal stability between bicortical resorbable and titanium screw fixation after sagittal split ramus osteotomy for mandibular prognathism. J. Cranio Maxillofac. Surg. 2012, 40, 660-664. [CrossRef] [PubMed]

166. Buijs, G.; van Bakelen, N.; Jansma, J.; de Visscher, J.; Hoppenreijs, T.; Bergsma, J.; Stegenga, B.; Bos, R. A randomized clinical trial of biodegradable and titanium fixation systems in maxillofacial surgery. J. Dent. Res. 2012, 91, 299-304. [CrossRef] [PubMed]

167. Bhatnagar, A.; Bansal, V.; Kumar, S.; Mowar, A. Comparative analysis of osteosynthesis of mandibular anterior fractures following open reduction using "stainless steel lag screws and mini plates”. J. Maxillofac. Oral Surg. 2013, 12, 133-139. [CrossRef] [PubMed]

168. Bender, S.; Chalivendra, V.; Rahbar, N.; el Wakil, S. Mechanical characterization and modeling of graded porous stainless steel specimens for possible bone implant applications. Int. J. Eng. Sci. 2012, 53, 67-73. [CrossRef]

169. Chew, K.K.; Hussein, S.Z.S.; Ahmad, A.L.; McPhail, D.S.; Boccaccini, A.R. Corrosion resistance study of electrophoretic deposited hydroxyapatite on stainless steel for implant applications. Key Eng. Mater. 2012, 507, 141-146. [CrossRef]

170. Zivic, F.; Babic, M.; Grujovic, N.; Mitrovic, S.; Adamovic, D. Influence of loose PMMA bone cement particles on the corrosion assisted wear of the orthopedic AISI 316LVM stainless steel during reciprocating sliding. Wear 2013, 300, 65-77. [CrossRef]

171. Vallittu, P.K.; Närhi, T.O.; Hupa, L. Fiber glass-bioactive glass composite for bone replacing and bone anchoring implants. Dent. Mater. 2015, 31, 371-381. [CrossRef] [PubMed]

172. Yamamuro, T. Clinical applications of bioactive glass-ceramics. New Mater. Technol. Healthc. 2012, 1, 1-97.

173. Rahaman, M.N.; Liu, X.; Bal, B.S.; Day, D.E.; Bi, L.; Bonewald, L.F. Bioactive glass in bone tissue engineering. Biomater. Sci. 2012, 237, 73-82.

174. Hench, L.L. Chronology of bioactive glass development and clinical applications. Sci. Res. 2013, 3, 67-73. [CrossRef]

175. Balani, K.; Narayan, R.; Agarwal, A.; Verma, V. Surface engineering and modification for biomedical applications. Biosurfaces 2015. [CrossRef] 
176. Fiorilli, S.; Baino, F.; Cauda, V.; Crepaldi, M.; Vitale-Brovarone, C.; Demarchi, D.; Onida, B. Electrophoretic deposition of mesoporous bioactive glass on glass-ceramic foam scaffolds for bone tissue engineering. J. Mater. Sci. 2015, 26, 1-12. [CrossRef] [PubMed]

177. Bagheri, Z.S.; Giles, E.; El Sawi, I.; Amleh, A.; Schemitsch, E.H.; Zdero, R.; Bougherara, H. Osteogenesis and cytotoxicity of a new carbon fiber/flax/epoxy composite material for bone fracture plate applications. Mater. Sci. Eng. 2015, 46, 435-442. [CrossRef] [PubMed]

178. Pietrzak, W.S.; Sarver, D.R.; Verstynen, M.L. Bioabsorbable polymer science for the practicing surgeon. J. Craniofac. Surg 1997, 8, 87-91. [CrossRef] [PubMed]

179. Miller, R.A.; Brady, J.M.; Cutright, D.E. Degradation rates of oral resorbable implants (polylactates and polyglycolates): Rate modification with changes in PLA/PGA copolymer ratios. J. Biomed. Mater. Res. 1977, 11, 711-719. [CrossRef] [PubMed]

180. Bertesteanu, S.; Chifiriuc, M.C.; Grumezescu, A.M.; Printza, A.G.; Marie-Paule, T.; Grumezescu, V.; Mihaela, V.; Lazar, V.; Grigore, R. Biomedical applications of synthetic, biodegradable polymers for the development of anti-infective strategies. Curr. Med. Chem. 2014, 21, 3383-3390. [CrossRef] [PubMed]

181. Ulery, B.D.; Nair, L.S.; Laurencin, C.T. Biomedical applications of biodegradable polymers. J. Polymer Sci. Part B Polymer Phys. 2011, 49, 832-864. [CrossRef] [PubMed]

182. Li, S.; Garreau, H.; Vert, M. Structure-property relationships in the case of the degradation of massive poly ( $\alpha$-hydroxy acids) in aqueous media. J. Mater. Sci. 1990, 1, 198-206.

183. Lloyd, A.W. Interfacial bioengineering to enhance surface biocompatibility. Med. Device Technol. 2001, 13, 18-21.

184. Domb, A.J.; Kost, J.; Wiseman, D. Handbook of Biodegradable Polymers; CRC Press: Boca Raton, FL, USA, 1998; Volume 7.

185. Shalaby, S.W.; Burg, K.J. Absorbable and Biodegradable Polymers; CRC Press: Boca Raton, FL, USA, 2003.

186. Pachence, J.M.; Kohn, J. Biodegradable polymers. Princ. Tissue Eng. 2000, 3, 323-339.

187. Nair, L.S.; Laurencin, C.T. Biodegradable polymers as biomaterials. Prog. Polymer Sci. 2007, 32, 762-798. [CrossRef]

188. Altman, G.H.; Diaz, F.; Jakuba, C.; Calabro, T.; Horan, R.L.; Chen, J.; Lu, H.; Richmond, J.; Kaplan, D.L. Silk-based biomaterials. Biomaterials 2003, 24, 401-416. [CrossRef]

189. Pachence, J.; Berg, R.; Silver, F. Collagen: Its place in the medical device industry. Med. Device Diagn. Ind. 1987, 9, 49-55.

190. Chevallay, B.; Herbage, D. Collagen-based biomaterials as $3 \mathrm{~d}$ scaffold for cell cultures: Applications for tissue engineering and gene therapy. Med. Biol. Eng. Comput. 2000, 38, 211-218. [CrossRef] [PubMed]

191. Reddi, A.H. Role of morphogenetic proteins in skeletal tissue engineering and regeneration. Nat. Biotechnol. 1998, 16, 247-252. [CrossRef] [PubMed]

192. Wang, Y.; Yang, C.; Chen, X.; Zhao, N. Biomimetic formation of hydroxyapatite/collagen matrix composite. Adv. Eng. Mater. 2006, 8, 97-100. [CrossRef] 
193. Roveri, N.; Falini, G.; Sidoti, M.; Tampieri, A.; Landi, E.; Sandri, M.; Parma, B. Biologically inspired growth of hydroxyapatite nanocrystals inside self-assembled collagen fibers. Mater. Sci. Eng. 2003, 23, 441-446. [CrossRef]

194. Zhang, W.; Liao, S.; Cui, F. Hierarchical self-assembly of nano-fibrils in mineralized collagen. Chem. Mater. 2003, 15, 3221-3226. [CrossRef]

195. Kikuchi, M.; Itoh, S.; Ichinose, S.; Shinomiya, K.; Tanaka, J. Self-organization mechanism in a bone-like hydroxyapatite/collagen nanocomposite synthesized in vitro and its biological reaction in vivo. Biomaterials 2001, 22, 1705-1711. [CrossRef]

196. Rhee, S.H.; Lee, J.D.; Tanaka, J. Nucleation of hydroxyapatite crystal through chemical interaction with collagen. J. Am. Ceram. Soc. 2000, 83, 2890-2892. [CrossRef]

197. Hsu, F.Y.; Chueh, S.-C.; Wang, Y.J. Microspheres of hydroxyapatite/reconstituted collagen as supports for osteoblast cell growth. Biomaterials 1999, 20, 1931-1936. [CrossRef]

198. Brodie, J.; Goldie, E.; Connel, G.; Merry, J.; Grant, M. Osteoblast interactions with calcium phosphate ceramics modified by coating with type I collagen. J. Biomed. Mater. Res. A 2005, 73, 409-421. [CrossRef] [PubMed]

199. Rodrigues, C.; Serricella, P.; Linhares, A.; Guerdes, R.; Borojevic, R.; Rossi, M.; Duarte, M.; Farina, M. Characterization of a bovine collagen-hydroxyapatite composite scaffold for bone tissue engineering. Biomaterials 2003, 24, 4987-4997. [CrossRef]

200. Zou, C.; Weng, W.; Deng, X.; Cheng, K.; Liu, X.; Du, P.; Shen, G.; Han, G. Preparation and characterization of porous beta-tricalcium phosphate/collagen composites with an integrated structure. Biomaterials 2005, 26, 5276-5284. [CrossRef] [PubMed]

201. Schneiders, W.; Reinstorf, A.; Pompe, W.; Grass, R.; Biewener, A.; Holch, M.; Zwipp, H.; Rammelt, S. Effect of modification of hydroxyapatite/collagen composites with sodium citrate, phosphoserine, phosphoserine/rgd-peptide and calcium carbonate on bone remodelling. Bone 2007, 40, 1048-1059. [CrossRef] [PubMed]

202. Marouf, H.A.; Quayle, A.A.; Sloan, P. In vitro and in vivo studies with collagen/hydroxyapatite implants. Int. J. Oral Maxillofac. Implants 1989, 5, 148-154.

203. Brown, W.E. A new calcium phosphate, water-setting cement. Cements Res. Prog. 1987, 351-379.

204. Barralet, J.; Grover, L.; Gbureck, U. Ionic modification of calcium phosphate cement viscosity. Part II: Hypodermic injection and strength improvement of brushite cement. Biomaterials 2004, 25, 2197-2203. [CrossRef] [PubMed]

205. Kumar, M.N.R. A review of chitin and chitosan applications. React. Funct. Polymers 2000, 46, 1-27. [CrossRef]

206. Madihally, S.V.; Matthew, H.W. Porous chitosan scaffolds for tissue engineering. Biomaterials 1999, 20, 1133-1142. [CrossRef]

207. Athanasiou, K.A.; Shah, A.R.; Hernandez, R.J.; LeBaron, R.G. Basic science of articular cartilage repair. Clin. Sports Med. 2001, 20, 223-247. [CrossRef]

208. Dornish, M.; Kaplan, D.; Skaugrud, Ø. Standards and guidelines for biopolymers in tissue-engineered medical products. Ann. New York Acad. Sci. 2001, 944, 388-397. [CrossRef] 
209. Shi, C.; Zhu, Y.; Ran, X.; Wang, M.; Su, Y.; Cheng, T. Therapeutic potential of chitosan and its derivatives in regenerative medicine. J. Surg. Res. 2006, 133, 185-192. [CrossRef] [PubMed]

210. Seeherman, H.; Li, R.; Wozney, J. A review of preclinical program development for evaluating injectable carriers for osteogenic factors. J. Bone Joint Surg. 2003, 85, 96-108. [PubMed]

211. Chesnutt, B.M.; Viano, A.M.; Yuan, Y.; Yang, Y.; Guda, T.; Appleford, M.R.; Ong, J.L.; Haggard, W.O.; Bumgardner, J.D. Design and characterization of a novel chitosan/nanocrystalline calcium phosphate composite scaffold for bone regeneration. J. Biomed. Mater. Res. A 2009, 88, 491-502. [CrossRef] [PubMed]

212. Lee, E.-J.; Shin, D.-S.; Kim, H.-E.; Kim, H.-W.; Koh, Y.-H.; Jang, J.-H. Membrane of hybrid chitosan-silica xerogel for guided bone regeneration. Biomaterials 2009, 30, 743-750. [CrossRef] [PubMed]

213. Zhou, H.; Qian, J.; Wang, J.; Yao, W.; Liu, C.; Chen, J.; Cao, X. Enhanced bioactivity of bone morphogenetic protein-2 with low dose of 2-n, 6-o-sulfated chitosan in vitro and in vivo. Biomaterials 2009, 30, 1715-1724. [CrossRef] [PubMed]

214. Vert, M.; Li, S.; Spenlehauer, G.; Guérin, P. Bioresorbability and biocompatibility of aliphatic polyesters. J. Mater. Sci. 1992, 3, 432-446. [CrossRef]

215. Seal, B.; Otero, T.; Panitch, A. Polymeric biomaterials for tissue and organ regeneration. Mater. Sci. Eng. 2001, 34, 147-230. [CrossRef]

216. Mano, J.F.; Sousa, R.A.; Boesel, L.F.; Neves, N.M.; Reis, R.L. Bioinert, biodegradable and injectable polymeric matrix composites for hard tissue replacement: State of the art and recent developments. Compos. Sci. Technol. 2004, 64, 789-817. [CrossRef]

217. Kohn, J. Bioresorbable and Bioerodible Materials. In Biomaterials Science: An Introduction to Materials in Medicine; Academic Press: San Diego, CA, USA, 1996.

218. Jagur-Grodzinski, J. Biomedical application of functional polymers. React. Funct. Polymers 1999, 39, 99-138. [CrossRef]

219. Griffith, L. Polymeric biomaterials. Acta Mater. 2000, 48, 263-277. [CrossRef]

220. Rezwan, K.; Chen, Q.; Blaker, J.; Boccaccini, A.R. Biodegradable and bioactive porous polymer/inorganic composite scaffolds for bone tissue engineering. Biomaterials 2006, 27, 3413-3431. [CrossRef] [PubMed]

221. Godbey, W.; Atala, A. In vitro systems for tissue engineering. Ann. New York Acad. Sci. 2002, 961, 10-26. [CrossRef]

222. Helmus, M.N.; Hubbell, J.A. Materials selection. Cardiovasc. Pathol. 1993, 2, 53-71. [CrossRef]

223. Kulkarni, R.; Moore, E.; Hegyeli, A.; Leonard, F. Biodegradable poly (lactic acid) polymers. J. Biomed. Mater. Res. 1971, 5, 169-181. [CrossRef] [PubMed]

224. Ma, P.X.; Zhang, R.; Xiao, G.; Franceschi, R. Engineering new bone tissue in vitro on highly porous poly ( $\alpha$-hydroxyl acids)/hydroxyapatite composite scaffolds. J. Biomed. Mater. Res. 2001, 54, 284-293. [CrossRef]

225. Vert, M.; Mauduit, J.; Li, S. Biodegradation of PLA/GA polymers: Increasing complexity. Biomaterials 1994, 15, 1209-1213. [CrossRef] 
226. Winet, H.; Bao, J. Comparative bone healing near eroding polylactide-polyglycolide implants of differing crystallinity in rabbit tibial bone chambers. J. Biomater. Sci. Polymer Ed. 1997, 8, 517-532. [CrossRef]

227. Martin, C.; Winet, H.; Bao, J. Acidity near eroding polylactide-polyglycolide in vitro and in vivo in rabbit tibial bone chambers. Biomaterials 1996, 17, 2373-2380. [CrossRef]

228. Agrawal, C.M.; Athanasiou, K.A. Technique to control pH in vicinity of biodegrading PLA-PGA implants. J. Biomed. Mater. Res. 1997, 38, 105-114. [CrossRef]

229. Reed, A.; Gilding, D. Biodegradable polymers for use in surgery-poly (glycolic)/poly (iactic acid) homo and copolymers: 2. In vitro degradation. Polymer 1981, 22, 494-498. [CrossRef]

230. Ikada, Y.; Tsuji, H. Biodegradable polyesters for medical and ecological applications. Macromol. Rapid Commun. 2000, 21, 117-132. [CrossRef]

231. Athanasiou, K.A.; Niederauer, G.G.; Agrawal, C.M. Sterilization, toxicity, biocompatibility and clinical applications of polylactic acid/polyglycolic acid copolymers. Biomaterials 1996, 17, 93-102. [CrossRef]

232. McVicar, I.; Hatton, P.; Brook, I. Self-reinforced polyglycolic acid membrane: A bioresorbable material for orbital floor repair. Initial clinical report. Br. J. Oral Maxillofac. Surg. 1995, 33, 220-223. [CrossRef]

233. Maurus, P.B.; Kaeding, C.C. Bioabsorbable implant material review. Oper. Tech. Sports Med. 2004, 12, 158-160. [CrossRef]

234. Törmälä, P.; Vasenius, J.; Vainionpää, S.; Laiho, J.; Pohjonen, T.; Rokkanen, P. Ultra-high-strength absorbable self-reinforced polyglycolide (SR-PGA) composite rods for internal fixation of bone fractures: In vitro and in vivo study. J. Biomed. Mater. Res. 1991, 25, 1-22. [CrossRef] [PubMed]

235. Cutright, D.E.; Perez, B.; Beasley, J.D.; Larson, W.J.; Posey, W.R. Degradation rates of polymers and copolymers of polylactic and polyglycolic acids. Oral Surg. Oral Med. Oral Pathol. 1974, 37, 142-152. [CrossRef]

236. Datta, R.; Henry, M. Lactic acid: Recent advances in products, processes and technologies-A review. J. Chem. Technol. Biotechnol. 2006, 81, 1119-1129. [CrossRef]

237. Garlotta, D. A literature review of poly (lactic acid). J. Polym. Environ. 2001, 9, 63-84. [CrossRef]

238. Argarate, N.; Olalde, B.; Atorrasagasti, G.; Valero, J.; Cifuentes, S.C.; Benavente, R.; Lieblich, M.; González-Carrasco, J.L. Biodegradable bi-layered coating on polymeric orthopaedic implants for controlled release of drugs. Mater. Lett. 2014, 132, 193-195. [CrossRef]

239. Tsuji, H.; Ikada, Y. Blends of aliphatic polyesters. Ii. Hydrolysis of solution-cast blends from poly (L-lactide) and poly (e-caprolactone) in phosphate-buffered solution. J. Appl. Polym. Sci. 1998, 67, 405-415. [CrossRef]

240. Sinclair, R. The case for polylactic acid as a commodity packaging plastic. J. Macromol. Sci. A 1996, 33, 585-597. [CrossRef]

241. Sawai, D.; Takahashi, K.; Imamura, T.; Nakamura, K.; Kanamoto, T.; Hyon, S.H. Preparation of oriented $\beta$-form poly (L-lactic acid) by solid-state extrusion. J. Polym. Sci. B 2002, 40, 95-104. [CrossRef] 
242. Iwata, T.; Doi, Y. Morphology and enzymatic degradation of poly (L-lactic acid) single crystals. Macromolecules 1998, 31, 2461-2467. [CrossRef]

243. Urayama, H.; Kanamori, T.; Kimura, Y. Properties and biodegradability of polymer blends of poly (L-lactide) s with different optical purity of the lactate units. Macromol. Mater. Eng. 2002, 287, 116-121. [CrossRef]

244. Andersson, S.R.; Hakkarainen, M.; Inkinen, S.; Södergård, A.; Albertsson, A.-C. Polylactide stereocomplexation leads to higher hydrolytic stability but more acidic hydrolysis product pattern. Biomacromolecules 2010, 11, 1067-1073. [CrossRef] [PubMed]

245. Sabir, M.I.; Xu, X.; Li, L. A review on biodegradable polymeric materials for bone tissue engineering applications. J. Mater. Sci. 2009, 44, 5713-5724. [CrossRef]

246. Sherwood, J.K.; Riley, S.L.; Palazzolo, R.; Brown, S.C.; Monkhouse, D.C.; Coates, M.; Griffith, L.G.; Landeen, L.K.; Ratcliffe, A. A three-dimensional osteochondral composite scaffold for articular cartilage repair. Biomaterials 2002, 23, 4739-4751. [CrossRef]

247. Grandfils, C.; Flandroy, P.; Nihant, N.; Barbette, S.; Jérôme, R.; Teyssié, P.; Thibaut, A. Preparation of poly (D, L) lactide microspheres by emulsion-solvent evaporation, and their clinical applications as a convenient embolic material. J. Biomed. Mater. Res. 1992, 26, 467-479. [CrossRef] [PubMed]

248. Schwartz, I.; Robinson, B.P.; Hollinger, J.O.; Szachowicz, E.H.; Brekke, J. Calvarial bone repair with porous d, L-polylactide. Otolaryngology 1995, 112, 707-713. [CrossRef]

249. Sheridan, M.; Shea, L.; Peters, M.; Mooney, D. Bioabsorbable polymer scaffolds for tissue engineering capable of sustained growth factor delivery. J. Controll. Release 2000, 64, 91-102. [CrossRef]

250. Zhang, R.; Ma, P.X. Porous poly (L-lactic acid)/apatite composites created by biomimetic process. J. Biomed. Mater. Res. 1999, 45, 285-293. [CrossRef]

251. Mikos, A.G.; Thorsen, A.J.; Czerwonka, L.A.; Bao, Y.; Langer, R.; Winslow, D.N.; Vacanti, J.P. Preparation and characterization of poly (L-lactic acid) foams. Polymer 1994, 35, 1068-1077. [CrossRef]

252. Schugens, C.; Maquet, V.; Grandfils, C.; Jérôme, R.; Teyssie, P. Polylactide macroporous biodegradable implants for cell transplantation. II. Preparation of polylactide foams by liquid-liquid phase separation. J. Biomed. Mater. Res. 1996, 30, 449-461. [CrossRef]

253. Wei, G.; Ma, P.X. Macroporous and nanofibrous polymer scaffolds and polymer/bone-like apatite composite scaffolds generated by sugar spheres. J. Biomed. Mater. Res. A 2006, 78, 306-315. [CrossRef] [PubMed]

254. Mathieu, L.M.; Mueller, T.L.; Bourban, P.-E.; Pioletti, D.P.; Müller, R.; Månson, J.-A.E. Architecture and properties of anisotropic polymer composite scaffolds for bone tissue engineering. Biomaterials 2006, 27, 905-916. [CrossRef] [PubMed]

255. Jie, W.; Yubao, L. Tissue engineering scaffold material of nano-apatite crystals and polyamide composite. Eur. Polym. J. 2004, 40, 509-515. [CrossRef]

256. Wei, J.; Li, Y.; Lau, K.-T. Preparation and characterization of a nano apatite/polyamide 6 bioactive composite. Compos. B 2007, 38, 301-305. [CrossRef] 
257. Flahiff, C.M.; Blackwell, A.S.; Hollis, J.M.; Feldman, D.S. Analysis of a biodegradable composite for bone healing. J. Biomed. Mater. Res. 1996, 32, 419-424. [CrossRef]

258. Ramay, H.R.; Zhang, M. Biphasic calcium phosphate nanocomposite porous scaffolds for load-bearing bone tissue engineering. Biomaterials 2004, 25, 5171-5180. [CrossRef] [PubMed]

259. Gunatillake, P.; Mayadunne, R.; Adhikari, R. Recent developments in biodegradable synthetic polymers. Biotechnol. Annu. Rev. 2006, 12, 301-347. [PubMed]

260. Hollinger, J.O. Preliminary report on the osteogenic potential of a biodegradable copolymer of polyactide (PLA) and polyglycolide (PGA). J. Biomed. Mater. Res. 1983, 17, 71-82. [CrossRef] [PubMed]

261. Nelson, J.F.; Stanford, H.G.; Cutright, D.E. Evaluation and comparisons of biodegradable substances as osteogenic agents. Oral Surg. Oral Med. Oral Pathol. 1977, 43, 836-843. [CrossRef]

262. Gunatillake, P.A.; Adhikari, R. Biodegradable synthetic polymers for tissue engineering. Eur. Cell Mater. 2003, 5, 1-16. [PubMed]

263. Lee, S.J.; Khang, G.; Lee, Y.M.; Lee, H.B. Interaction of human chondrocytes and NIH/3T3 fibroblasts on chloric acid-treated biodegradable polymer surfaces. J. Biomater. Sci. Polym. Ed. 2002, 13, 197-212. [CrossRef] [PubMed]

264. Södergård, A.; Stolt, M. Properties of lactic acid based polymers and their correlation with composition. Prog. Polym. Sci. 2002, 27, 1123-1163. [CrossRef]

265. Murphy, W.L.; Kohn, D.H.; Mooney, D.J. Growth of continuous bonelike mineral within porous poly (lactide-co-glycolide) scaffolds in vitro. J. Biomed. Mater. Res. 2000, 50, 50-58. [CrossRef]

266. Knepper-Nicolai, B.; Reinstorf, A.; Hofinger, I.; Flade, K.; Wenz, R.; Pompe, W. Influence of osteocalcin and collagen I on the mechanical and biological properties of biocement D. Biomol. Eng. 2002, 19, 227-231. [CrossRef]

267. Friedman, C.D.; Costantino, P.D.; Takagi, S.; Chow, L.C. BonesourceTM hydroxyapatite cement: A novel biomaterial for craniofacial skeletal tissue engineering and reconstruction. J. Biomed. Mater. Res. 1998, 43, 428-432. [CrossRef]

268. Huang, J.; Best, S.; Bonfield, W.; Brooks, R.; Rushton, N.; Jayasinghe, S.; Edirisinghe, M. In vitro assessment of the biological response to nano-sized hydroxyapatite. J. Mater. Sci. 2004, 15, 441-445. [CrossRef]

269. Pezzatini, S.; Solito, R.; Morbidelli, L.; Lamponi, S.; Boanini, E.; Bigi, A.; Ziche, M. The effect of hydroxyapatite nanocrystals on microvascular endothelial cell viability and functions. J. Biomed. Mater. Res. A 2006, 76, 656-663. [CrossRef] [PubMed]

270. Zimmermann, B.; Wachtel, H.; Noppe, C. Patterns of mineralization in vitro. Cell Tissue Res. 1991, 263, 483-493. [CrossRef] [PubMed]

271. Ciapetti, G.; Ambrosio, L.; Savarino, L.; Granchi, D.; Cenni, E.; Baldini, N.; Pagani, S.; Guizzardi, S.; Causa, F.; Giunti, A. Osteoblast growth and function in porous poly $\varepsilon$-caprolactone matrices for bone repair: A preliminary study. Biomaterials 2003, 24, 3815-3824. [CrossRef]

272. Yuan, H.; Kurashina, K.; de Bruijn, J.D.; Li, Y.; de Groot, K.; Zhang, X. A preliminary study on osteoinduction of two kinds of calcium phosphate ceramics. Biomaterials 1999, 20, 1799-1806. [CrossRef] 
273. Kuboki, Y.; Jin, Q.; Takita, H. Geometry of carriers controlling phenotypic expression in bmp-induced osteogenesis and chondrogenesis. J. Bone Joint Surg. 2001, 83, S105-S115. [PubMed]

274. Tamai, N.; Myoui, A.; Hirao, M.; Kaito, T.; Ochi, T.; Tanaka, J.; Takaoka, K.; Yoshikawa, H. A new biotechnology for articular cartilage repair: Subchondral implantation of a composite of interconnected porous hydroxyapatite, synthetic polymer (PLA-PEG), and bone morphogenetic protein-2 (rhBMP-2). Osteoarthr. Cartil. 2005, 13, 405-417. [CrossRef] [PubMed]

275. Zhang, P.; Hong, Z.; Yu, T.; Chen, X.; Jing, X. In vivo mineralization and osteogenesis of nanocomposite scaffold of poly (lactide-co-glycolide) and hydroxyapatite surface-grafted with poly (L-lactide). Biomaterials 2009, 30, 58-70. [CrossRef] [PubMed]

276. Labet, M.; Thielemans, W. Synthesis of polycaprolactone: A review. Chem. Soc. Rev. 2009, 38, 3484-3504. [CrossRef] [PubMed]

277. Kweon, H.; Yoo, M.K.; Park, I.K.; Kim, T.H.; Lee, H.C.; Lee, H.-S.; Oh, J.-S.; Akaike, T.; Cho, C.-S. A novel degradable polycaprolactone networks for tissue engineering. Biomaterials 2003, 24, 801-808. [CrossRef] [PubMed]

278. Engelberg, I.; Kohn, J. Physico-mechanical properties of degradable polymers used in medical applications: A comparative study. Biomaterials 1991, 12, 292-304. [CrossRef]

279. Coombes, A.; Rizzi, S.; Williamson, M.; Barralet, J.; Downes, S.; Wallace, W. Precipitation casting of polycaprolactone for applications in tissue engineering and drug delivery. Biomaterials 2004, 25, 315-325. [CrossRef]

280. Agrawal, C.; Ray, R.B. Biodegradable polymeric scaffolds for musculoskeletal tissue engineering. J. Biomed. Mater. Res. 2001, 55, 141-150. [CrossRef]

281. Mondrinos, M.J.; Dembzynski, R.; Lu, L.; Byrapogu, V.K.; Wootton, D.M.; Lelkes, P.I.; Zhou, J. Porogen-based solid freeform fabrication of polycaprolactone-calcium phosphate scaffolds for tissue engineering. Biomaterials 2006, 27, 4399-4408. [CrossRef] [PubMed]

282. Ramakrishna, S.; Mayer, J.; Wintermantel, E.; Leong, K.W. Biomedical applications of polymer-composite materials: A review. Compos. Sci. Technol. 2001, 61, 1189-1224. [CrossRef]

283. Benedetti, L.; Cortivo, R.; Berti, T.; Berti, A.; Pea, F.; Mazzo, M.; Moras, M.; Abatangelo, G. Biocompatibility and biodegradation of different hyaluronan derivatives (Hyaff) implanted in rats. Biomaterials 1993, 14, 1154-1160. [CrossRef]

284. Giordano, C.; Sanginario, V.; Ambrosio, L.; di Silvio, L.; Santin, M. Chemical-physical characterization and in vitro preliminary biological assessment of hyaluronic acid benzyl ester-hydroxyapatite composite. J. Biomater. Appl. 2006, 20, 237-252. [CrossRef] [PubMed]

285. Mori, M.; Yamaguchi, M.; Sumitomo, S.; Takai, Y. Hyaluronan-based biomaterials in tissue engineering. Acta Histochem. Cytochem. 2004, 37, 1-5. [CrossRef]

286. Sanginario, V.; Ginebra, M.; Tanner, K.; Planell, J.; Ambrosio, L. Biodegradable and semi-biodegradable composite hydrogels as bone substitutes: Morphology and mechanical characterization. J. Mater. Sci. 2006, 17, 447-454. [CrossRef] [PubMed]

287. Hollinger, J.O; Battistone, G.C. Biodegradable bone repair materials synthetic polymers and ceramics. Clin. Orthop. Relat. Res. 1986, 207, 290-306. [PubMed]

288. Yang, K.-K.; Wang, X.-L.; Wang, Y.-Z. Poly (p-dioxanone) and its copolymers. J. Macromol. Sci. Part C 2002, 42, 373-398. [CrossRef] 
289. Pezzin, A.; Ekenstein, V.; Alberda, G.; Zavaglia, C.; Ten Brinke, G.; Duek, E. Poly (para-dioxanone) and poly (L-lactic acid) blends: Thermal, mechanical, and morphological properties. J. Appl. Polymer Sci. 2003, 88, 2744-2755. [CrossRef]

290. Bai, W.; Zhang, Z.p.; Li, Q.; Chen, D.L.; Chen, H.C.; Zhao, N.; Xiong, C.D. Miscibility, morphology and thermal properties of poly (para-dioxanone)/poly (d, L-lactide) blends. Polymer Int. 2009, 58, 183-189. [CrossRef]

291. Pietrzak, W.S. Principles of development and use of absorbable internal fixation. Tissue Eng. 2000, 6, 425-433. [CrossRef] [PubMed]

292. Roller, M.B.; Li, Y.; Yuan, J.J. Implantable Medical Devices and Methods for Making Same. U.S. Patent 7,572,298, 11 August 2009.

293. Shi, D. Introduction to Biomaterials; World Scientific: Singapore, Singapore, 2006.

294. Bai, W.; Chen, D.; Li, Q.; Chen, H.; Zhang, S.; Huang, X.; Xiong, C.-D. In vitro hydrolytic degradation of poly (para-dioxanone) with high molecular weight. J. Polym. Res. 2009, 16, 471-480. [CrossRef]

295. Bai, W.; Zhang, L.-F.; Li, Q.; Chen, D.-L.; Xiong, C.-D. In vitro hydrolytic degradation of poly (para-dioxanone)/poly (D, L-lactide) blends. Mater. Chem. Phys. 2010, 122, 79-86. [CrossRef]

296. Ward, I.M.; Sweeney, J. Mechanical Properties of Solid Polymers; John Wiley \& Sons: Hoboken, NJ, USA, 2012.

297. Schimming, R.; Schmelzeisen, R. Tissue-engineered bone for maxillary sinus augmentation. J. Oral Maxillofac. Surg. 2004, 62, 724-729. [CrossRef] [PubMed]

298. Hutmacher, D.W. Scaffolds in tissue engineering bone and cartilage. Biomaterials 2000, 21, 2529-2543. [CrossRef]

299. Mallick, P.K. Fiber-Reinforced Composites: Materials, Manufacturing, and Design; CRC Press: Boca Raton, FL, USA, 2010.

300. Mehboob, H.; Chang, S.-H. Application of composites to orthopedic prostheses for effective bone healing: A review. Compos. Struct. 2014, 118, 328-341. [CrossRef]

301. Andriano, K.P.; Daniels, A.; Heller, J. Biocompatibility and mechanical properties of a totally absorbable composite material for orthopaedic fixation devices. J. Appl. Biomater. 1992, 3, 197-206. [CrossRef] [PubMed]

302. Harper, L.; Ahmed, I.; Felfel, R.; Qian, C. Finite element modelling of the flexural performance of resorbable phosphate glass fibre reinforced pla composite bone plates. J. Mech. Behav. Biomed. Mater. 2012, 15, 13-23. [CrossRef] [PubMed]

303. Parsons, A.J.; Ahmed, I.; Haque, P.; Fitzpatrick, B.; Niazi, M.I.; Walker, G.S.; Rudd, C.D. Phosphate glass fibre composites for bone repair. J. Bionic Eng. 2009, 6, 318-323. [CrossRef]

304. Haque, P.; Parsons, A.J.; Barker, I.A.; Ahmed, I.; Irvine, D.J.; Walker, G.S.; Rudd, C.D. Interfacial properties of phosphate glass fibres/PLA composites: Effect of the end functionalities of oligomeric pla coupling agents. Compos. Sci. Technol. 2010, 70, 1854-1860. [CrossRef]

305. Ahmed, I.; Jones, I.; Parsons, A.; Bernard, J.; Farmer, J.; Scotchford, C.; Walker, G.; Rudd, C. Composites for bone repair: Phosphate glass fibre reinforced PLA with varying fibre architecture. J. Mater. Sci. 2011, 22, 1825-1834. [CrossRef] [PubMed] 
306. Gupta, G.; Zbib, A.; el-Ghannam, A.; Khraisheh, M.; Zbib, H. Characterization of a novel bioactive composite using advanced X-ray computed tomography. Compos. Struct. 2005, 71, 423-428. [CrossRef]

307. Cannillo, V.; Chiellini, F.; Fabbri, P.; Sola, A. Production of bioglass ${ }^{\circledR}$ 45s5-polycaprolactone composite scaffolds via salt-leaching. Compos. Struct. 2010, 92, 1823-1832. [CrossRef]

308. Ahmed, I.; Parsons, A.; Palmer, G.; Knowles, J.; Walker, G.; Rudd, C. Weight loss, ion release and initial mechanical properties of a binary calcium phosphate glass fibre/PCL composite. Acta Biomater. 2008, 4, 1307-1314. [CrossRef] [PubMed]

309. Felfel, R.M.; Ahmed, I.; Parsons, A.J.; Haque, P.; Walker, G.S.; Rudd, C.D. Investigation of crystallinity, molecular weight change, and mechanical properties of PLA/PBG bioresorbable composites as bone fracture fixation plates. J. Biomater. Appl. 2012, 26, 765-789. [CrossRef] [PubMed]

310. Ahmed, I.; Cronin, P.; Abou Neel, E.; Parsons, A.; Knowles, J.; Rudd, C. Retention of mechanical properties and cytocompatibility of a phosphate-based glass fiber/polylactic acid composite. J. Biomed. Mater. Res. B 2009, 89, 18-27. [CrossRef] [PubMed]

311. Felfel, R.; Ahmed, I.; Parsons, A.; Rudd, C. Bioresorbable screws reinforced with phosphate glass fibre: Manufacturing and mechanical property characterisation. J. Mech. Behav. Biomed. Mater. 2013, 17, 76-88. [CrossRef] [PubMed]

312. Felfel, R.; Ahmed, I.; Parsons, A.; Rudd, C. Bioresorbable composite screws manufactured via forging process: Pull-out, shear, flexural and degradation characteristics. J. Mech. Behav. Biomed. Mater. 2013, 18, 108-122. [CrossRef] [PubMed]

313. Felfel, R.; Ahmed, I.; Parsons, A.; Harper, L.; Rudd, C. Initial mechanical properties of phosphate-glass fibre-reinforced rods for use as resorbable intramedullary nails. J. Mater. Sci. 2012, 47, 4884-4894. [CrossRef]

314. Hasan, M.S.; Ahmed, I.; Parsons, A.J.; Rudd, C.D.; Walker, G.S.; Scotchford, C.A. Investigating the use of coupling agents to improve the interfacial properties between a resorbable phosphate glass and polylactic acid matrix. J. Biomater. Appl. 2012, 28, 354-366. [CrossRef] [PubMed]

315. Felfel, R.; Ahmed, I.; Parsons, A.; Walker, G.; Rudd, C. In vitro degradation, flexural, compressive and shear properties of fully bioresorbable composite rods. J. Mech. Behav. Biomed. Mater. 2011, 4, 1462-1472. [CrossRef] [PubMed]

316. Hench, L.L. The story of bioglass ${ }^{\circledR}$. J. Mater. Sci. 2006, 17, 967-978. [CrossRef] [PubMed]

317. Sheikh, Z.A.A.; Javaid, M.A.; Abdallah, M.N. Bone replacement graft materials in dentistry. In Dental Biomaterials (Principle and Its Application), 2nd ed.; Khurshid, S.Z., Ed.; Paramount Publishing Enterprise: Karachi, Pakistan, 2014.

318. Sheikh, Z.; Geffers, M.; Christel, T.; Barralet, J.E.; Gbureck, U. Chelate setting of alkali ion substituted calcium phosphates. Ceram. Int. 2015, 41, 10010-10017. [CrossRef]

319. Lu, J.; Descamps, M.; Dejou, J.; Koubi, G.; Hardouin, P.; Lemaitre, J.; Proust, J.P. The biodegradation mechanism of calcium phosphate biomaterials in bone. J. Biomed. Mater. Res. 2002, 63, 408-412. [CrossRef] [PubMed]

320. Radin, S.; Campbell, J.T.; Ducheyne, P.; Cuckler, J.M. Calcium phosphate ceramic coatings as carriers of vancomycin. Biomaterials 1997, 18, 777-782. [CrossRef] 
321. Ogose, A.; Hotta, T.; Kawashima, H.; Kondo, N.; Gu, W.; Kamura, T.; Endo, N. Comparison of hydroxyapatite and beta tricalcium phosphate as bone substitutes after excision of bone tumors. J. Biomed. Mater. Res. Part B 2005, 72, 94-101. [CrossRef] [PubMed]

322. Daculsi, G.; LeGeros, R.; Heughebaert, M.; Barbieux, I. Formation of carbonate-apatite crystals after implantation of calcium phosphate ceramics. Calcif. Tissue Int. 1990, 46, 20-27. [CrossRef] [PubMed]

323. Shigaku, S.; Katsuyuki, F. Beta-tricalcium phosphate as a bone graft substitute. Jikeikai Med. J. 2005, 52, 47-54.

324. Hak, D.J. The use of osteoconductive bone graft substitutes in orthopaedic trauma. J. Am. Acad. Orthop. Surg. 2007, 15, 525-536. [PubMed]

325. Cameron, H.; Macnab, I.; Pilliar, R. Evaluation of a biodegradable ceramic. J. Biomed. Mater. Res. 1977, 11, 179-186. [CrossRef] [PubMed]

326. Skorokhod, V.; Solonin, S.; Dubok, V.; Kolomiets, L.; Katashinskii, V.; Shinkaruk, A. Pressing and sintering of nanosized hydroxyapatite powders. Powder Metall. Metal Ceram. 2008, 47, 518-524. [CrossRef]

327. Erbe, E.; Marx, J.; Clineff, T.; Bellincampi, L. Potential of an ultraporous $\beta$-tricalcium phosphate synthetic cancellous bone void filler and bone marrow aspirate composite graft. Eur. Spine J. 2001, 10, S141-S146. [PubMed]

328. Ryu, H.S.; Lee, J.K.; Seo, J.H.; Kim, H.; Hong, K.S.; Kim, D.J.; Lee, J.H.; Lee, D.H.; Chang, B.S.; Lee, C.K. Novel bioactive and biodegradable glass ceramics with high mechanical strength in the cao-SiO $\mathrm{S}_{2}-\mathrm{B}_{2} \mathrm{O}_{3}$ system. J. Biomed. Mater. Res. A 2004, 68, 79-89. [CrossRef] [PubMed]

329. Santos, M.; Valerio, P.; Goes, A.; Leite, M.; Heneine, L.; Mansur, H. Biocompatibility evaluation of hydroxyapatite/collagen nanocomposites doped with $\mathrm{Zn}^{2+}$. Biomed. Mater. 2007, 2. [CrossRef] [PubMed]

330. Irigaray, J.; Oudadesse, H.; Jallot, E.; Brun, V.; Weber, G.; Frayssinet, P. Materials in Clinical Applications; World Ceramics Congress and Forum on New Materials: Florence, Italy, 1999; pp. 399-403.

331. Nurit, J.; Margerit, J.; Terol, A.; Boudeville, P. Ph-metric study of the setting reaction of monocalcium phosphate monohydrate/calcium oxide-based cements. J. Mater. Sci. Mater. Med. 2002, 13, 1007-1014. [CrossRef] [PubMed]

332. Desai, T.R.; Bhaduri, S.B.; Tas, A.C. A self-setting, monetite (CaHPO4) cement for skeletal repair. Adv. Bioceram. Biocompos. II 2007, 27, 61-69.

333. Tamimi, F.; le Nihouannen, D.; Eimar, H.; Sheikh, Z.; Komarova, S.; Barralet, J. The effect of autoclaving on the physical and biological properties of dicalcium phosphate dihydrate bioceramics: Brushite vs. Monetite. Acta Biomater. 2012, 8, 3161-3169. [CrossRef] [PubMed]

334. Bohner, M.; Merkle, H.P.; Landuyt, P.V.; Trophardy, G.; Lemaitre, J. Effect of several additives and their admixtures on the physico-chemical properties of a calcium phosphate cement. J. Mater. Sci. Mater. Med. 1999, 11, 111-116. [CrossRef]

335. Pina, S.; Torres, P.M.; Goetz-Neunhoeffer, F.; Neubauer, J.; Ferreira, J.M.F. Newly developed Sr-substituted alpha-TCP bone cements. Acta Biomater. 2010, 6, 928-935. [CrossRef] [PubMed] 
336. Lilley, K.J.; Wright, A.J.; Farrar, D.; Barralet, J.E. Cement from nanocrystalline hydroxyapatite: Effect of sulphate ions. Bioceramics 2005, 284-286, 137-140. [CrossRef]

337. Marino, F.T.; Torres, J.; Hamdan, M.; Rodriguez, C.R.; Cabarcos, E.L. Advantages of using glycolic acid as a retardant in a brushite forming cement. J. Biomed. Mater. Res. Part B Appl. Biomater. 2007, 83, 571-579. [CrossRef] [PubMed]

338. Tamimi, F.; Torres, J.; Kathan, C.; Baca, R.; Clemente, C.; Blanco, L.; Cabarcos, E.L. Bone regeneration in rabbit calvaria with novel monetite granules. J. Biomed. Mater. Res. A 2008, 87, 980-985. [CrossRef] [PubMed]

339. Aberg, J.; Brisby, H.; Henriksson, H.; Lindahl, A.; Thomsen, P.; Engqvist, H. Premixed acidic calcium phosphate cement: Characterization of strength and microstructure. J. Biomed. Mater. Res. B 2010, 93, 436-441. [CrossRef] [PubMed]

340. Ryf, C.; Goldhahn, S.; Radziejowski, M.; Blauth, M.; Hanson, B. A new injectable brushite cement: First results in distal radius and proximal tibia fractures. Eur. J. Trauma Emerg. Surg. 2009, 35, 389-396. [CrossRef]

341. Frazer, R.Q.; Byron, R.T.; Osborne, P.B.; West, K.P. PMMA: An essential material in medicine and dentistry. J. Long Term Effects Med. Implants 2005, 15, 629-639. [CrossRef]

342. Horowitz, S.M.; Frondoza, C.G.; Lennox, D.W. Effects of polymethylmethacrylate exposure upon macrophages. J. Orthop. Res. 1988, 6, 827-832. [CrossRef] [PubMed]

343. Stürup, J.; Nimb, L.; Kramhøft, M.; Jensen, J.S. Effects of polymerization heat and monomers from acrylic cement on canine bone. Acta Orthop. 1994, 65, 20-23. [CrossRef]

344. Kalteis, T.; Lüring, C.; Gugler, G.; Zysk, S.; Caro, W.; Handel, M.; Grifka, J. Acute tissue toxicity of pmma bone cements. Z. Orthop. Ihre Grenzgeb. 2003, 142, 666-672. [CrossRef] [PubMed]

345. Seal, C.; Vince, K.; Hodgson, M. Biodegradable Surgical Implants Based on Magnesium Alloys-A Review of Current Research; IOP Publishing: Bristol, UK, 2009.

346. Kubota, K.; Mabuchi, M.; Higashi, K. Review processing and mechanical properties of fine-grained magnesium alloys. J. Mater. Sci. 1999, 34, 2255-2262. [CrossRef]

347. Brar, H.S.; Platt, M.O.; Sarntinoranont, M.; Martin, P.I.; Manuel, M.V. Magnesium as a biodegradable and bioabsorbable material for medical implants. JOM 2009, 61, 31-34. [CrossRef]

348. Mordike, B.; Ebert, T. Magnesium: Properties_applications-potential. Mater. Sci. Eng. 2001, 302, 37-45. [CrossRef]

349. Towle, D.; Friend, C. Comparison of compressive and tensile properties of magnesium based metal matrix composites. Mater. Sci. Technol. 1993, 9, 35-41. [CrossRef]

350. Lin, X.; Tan, L.; Zhang, Q.; Yang, K.; Hu, Z.; Qiu, J.; Cai, Y. The in vitro degradation process and biocompatibility of a ZK60 magnesium alloy with a forsterite-containing micro-arc oxidation coating. Acta Biomater. 2013, 9, 8631-8642. [CrossRef] [PubMed]

351. Gu, X.; Li, N.; Zhou, W.; Zheng, Y.; Zhao, X.; Cai, Q.; Ruan, L. Corrosion resistance and surface biocompatibility of a microarc oxidation coating on a Mg-Ca alloy. Acta Biomater. 2011, 7, 1880-1889. [CrossRef] [PubMed]

352. Song, G. Control of biodegradation of biocompatable magnesium alloys. Corros. Sci. 2007, 49, 1696-1701. [CrossRef] 
353. Geng, F.; Tan, L.; Jin, X.; Yang, J.; Yang, K. The preparation, cytocompatibility, and in vitro biodegradation study of pure $\beta$-TCP on magnesium. J. Mater. Sci. 2009, 20, 1149-1157. [CrossRef] [PubMed]

354. Xu, L.; Zhang, E.; Yang, K. Phosphating treatment and corrosion properties of Mg-Mn-Zn alloy for biomedical application. J. Mater. Sci. 2009, 20, 859-867. [CrossRef] [PubMed]

355. Wen, C.; Guan, S.; Peng, L.; Ren, C.; Wang, X.; Hu, Z. Characterization and degradation behavior of AZ31 alloy surface modified by bone-like hydroxyapatite for implant applications. Appl. Surf. Sci. 2009, 255, 6433-6438. [CrossRef]

356. Habibovic, P.; Barrere, F.; Blitterswijk, C.A.; Groot, K.; Layrolle, P. Biomimetic hydroxyapatite coating on metal implants. J. Am. Ceram. Soc. 2002, 85, 517-522. [CrossRef]

357. Wan, Y.; Xiong, G.; Luo, H.; He, F.; Huang, Y.; Zhou, X. Preparation and characterization of a new biomedical magnesium-calcium alloy. Mater. Des. 2008, 29, 2034-2037. [CrossRef]

358. Gu, X.; Zheng, W.; Cheng, Y.; Zheng, Y. A study on alkaline heat treated Mg-Ca alloy for the control of the biocorrosion rate. Acta Biomater. 2009, 5, 2790-2799. [CrossRef] [PubMed]

359. Gu, X.; Zheng, Y.; Cheng, Y.; Zhong, S.; Xi, T. In vitro corrosion and biocompatibility of binary magnesium alloys. Biomaterials 2009, 30, 484-498. [CrossRef] [PubMed]

360. Li, Z.; Gu, X.; Lou, S.; Zheng, Y. The development of binary Mg-Ca alloys for use as biodegradable materials within bone. Biomaterials 2008, 29, 1329-1344. [CrossRef] [PubMed]

361. Zhang, S.; Zhang, X.; Zhao, C.; Li, J.; Song, Y.; Xie, C.; Tao, H.; Zhang, Y.; He, Y.; Jiang, Y.; et al. Research on an Mg-Zn alloy as a degradable biomaterial. Acta Biomater. 2010, 6, 626-640. [CrossRef] [PubMed]

362. Boehlert, C.; Knittel, K. The microstructure, tensile properties, and creep behavior of Mg-Zn alloys containing 0-4.4 wt. \% Zn. Mater. Sci. Eng. 2006, 417, 315-321. [CrossRef]

363. Gooptu, B.; Lomas, D.A. Polymers and inflammation: Disease mechanisms of the serpinopathies. J. Exp. Med. 2008, 205, 1529-1534. [CrossRef] [PubMed]

364. Puoci, F. Advanced Polymers in Medicine; Springer: Berlin, Germany, 2015.

365. Van Der Giessen, W.J.; Lincoff, A.M.; Schwartz, R.S.; van Beusekom, H.M.; Serruys, P.W.; Holmes, D.R.; Ellis, S.G.; Topol, E.J. Marked inflammatory sequelae to implantation of biodegradable and nonbiodegradable polymers in porcine coronary arteries. Circulation 1996, 94, 1690-1697. [CrossRef] [PubMed]

366. Anderson, J.M. Inflammatory response to implants. ASAIO J. 1988, 34, 101-107. [CrossRef]

367. Rokkanen, P.; Bostman, O.; Makela, E.A.; Hirvensalo, E.; Partio, E.K.; Vihtonen, K.; Patiala, H.; Tormala, P. Absorbable devices in the fixation of fractures. J. Trauma Acute Care Surg. 1996, 40, 123S-127S. [CrossRef]

368. Bostman, O. Osteolytic changes accompanying degradation of absorbable fracture fixation implants. J. Bone Joint Surg. Br. Vol. 1991, 73, 679-682.

369. Böstman, O. Intense granulomatous inflammatory lesions associated with absorbable internal fixation devices made of polyglycolide in ankle fractures. Clin. Orthop. Relat. Res. 1992, 278, 193-199. [PubMed] 
370. Chaignaud, B.E.; Langer, R.; Vacanti, J.P. The history of tissue engineering using synthetic biodegradable polymer scaffolds and cells. In Synthetic Biodegradable Polymer Scaffolds; Springer: Berlin, Germany; Heidelberg, Germany, 1997; pp. 1-14.

371. Naughton, G.K.; Tolbert, W.R.; Grillot, T.M. Emerging developments in tissue engineering and cell technology. Tissue Eng. 1995, 1, 211-219. [CrossRef] [PubMed]

372. Athanasiou, K.; Schenck, R.; Constantinides, G.; Sylvia, V.; Aufdemorte, T.; Boyan, B. Biodegradable carriers of TGF-b in rabbit osteochondral defects. Trans. Orthop. Res. Soc. 1993, 18, 288.

373. Vacanti, J.P.; Langer, R. Tissue engineering: The design and fabrication of living replacement devices for surgical reconstruction and transplantation. Lancet 1999, 354, S32-S34. [CrossRef]

374. Agrawal, C.; Niederauer, G.; Micallef, D.; Athanasiou, K. The use of PLA-PGA polymers in orthopaedics. In Encyclopedic Handbook of Biomaterials and Bioengineering; Marcel Dekker: New York, NY, USA, 1995; pp. 2081-2115.

375. Bajpai, P. Biodegradable scaffolds in orthopedic, oral and maxillofacial surgery. Biomater. Reconstruct. Surg. 1983, 312-328.

376. Athanasiou, K.A.; Agrawal, C.M.; Barber, F.A.; Burkhart, S.S. Orthopaedic applications for pla-pga biodegradable polymers. Arthroscopy 1998, 14, 726-737. [CrossRef]

377. Jones, H.P.; Lemos, M.J.; Wilk, R.M.; Smiley, P.M.; Gutierrez, R.; Schepsis, A.A. Two-year follow-up of meniscal repair using a bioabsorbable arrow. Arthroscopy 2002, 18, 64-69. [CrossRef] [PubMed]

378. Suganuma, J.; Alexander, H. Biological response of intramedullary bone to poly-L-lactic acid. J. Appl. Biomater. 1993, 4, 13-27. [CrossRef]

379. Athanasiou, K. Biodegradable Scaffolds for Use in Orthopaedic Tissue Engineering. In Proceedings of the 1996 Fifteenth Southern Biomedical Engineering Conference, Dayton, OH, USA, 29-31 March 1996.

380. Hollinger, J.; Chaudhari, A. Bone regeneration materials for the mandibular and craniofacial complex. Cell Mater. 1992, 2, 143-151.

381. Hutmacher, D.W.; Kirsch, A.; Ackermann, K.L.; Hürzeler, M.B. A tissue engineered cell-occlusive device for hard tissue regeneration-A preliminary report. Int. J. Periodontics Restor. Dent. 2001, 21, 49-59.

382. Shikinami, Y.; Okuno, M. Bioresorbable devices made of forged composites of hydroxyapatite (HA) particles and poly-L-lactide (PLLA): Part I. Basic characteristics. Biomaterials 1999, 20, 859-877. [CrossRef]

383. Hutmacher, D.; Kirsch, A.; Ackermann, K.; Huerzeler, M. Matrix and carrier materials for bone growth factors: State of the art and future perspectives. In Biological Matrices and Tissue Reconstruction; Springer: Berlin, Germany; Heidelberg, Germany, 1998; pp. 197-206.

384. West, J.; Hubbell, J. Bioactive polymers, synthetic biodegradable polymer scaffolds. Chapter 5. In Bioactive Polymers; Springer: New York, NY, USA, 1986.

385. Gorzelanny, C.; Pöppelmann, B.; Pappelbaum, K.; Moerschbacher, B.M.; Schneider, S.W. Human macrophage activation triggered by chitotriosidase-mediated chitin and chitosan degradation. Biomaterials 2010, 31, 8556-8563. [CrossRef] [PubMed] 
386. Apelt, D.; Theiss, F.; EI-Warrak, A.O.; Zlinszky, K.; Bettschart-Wolfisberger, R.; Bohner, M.; Matter, S.; Auer, J.A.; von Rechenberg, B. In vivo behavior of three different injectable hydraulic calcium phosphate cements. Biomaterials 2004, 25, 1439-1451. [CrossRef] [PubMed]

387. Lu, J.X.; About, I.; Stephan, G.; van Landuyt, P.; Dejou, J.; Fiocchi, M.; Lemaitre, J.; Proust, J.P. Histological and biomechanical studies of two bone colonizable cements in rabbits. Bone 1999, 25, 41S-45S. [CrossRef]

388. Frayssinet, P.; Gineste, L.; Rouquet, N. Osteointegration of differents kinds of calcium phosphate biomaterials: Ceramics and hydraulic cements. Morphologie 1998, 82, 3-7. [PubMed]

389. Constantz, B.R.; Barr, B.M.; Ison, I.C.; Fulmer, M.T.; Baker, J.; McKinney, L.; Goodman, S.B.; Gunasekaren, S.; Delaney, D.C.; Ross, J.; et al. Histological, chemical, and crystallographic analysis of four calcium phosphate cements in different rabbit osseous sites. J. Biomed. Mater. Res. 1998, 43, 451-461. [CrossRef]

390. Kuemmerle, J.M.; Oberle, A.; Oechslin, C.; Bohner, M.; Frei, C.; Boecken, I.; von Rechenberg, B. Assessment of the suitability of a new brushite calcium phosphate cement for cranioplasty-An experimental study in sheep. J. Cranio Maxillofac. Surg. 2005, 33, 37-44. [CrossRef] [PubMed]

391. Grover, L.M.; Knowles, J.C.; Fleming, G.J.P.; Barralet, J.E. In vitro ageing of brushite calcium phosphate cement. Biomaterials 2003, 24, 4133-4141. [CrossRef]

392. Pioletti, D.P.; Takei, H.; Lin, T.; Van Landuyt, P.; Ma, Q.J.; Kwon, S.Y.; Sung, K.L.P. The effects of calcium phosphate cement particles on osteoblast functions. Biomaterials 2000, 21, 1103-1114. [CrossRef]

393. Meijer, G.J.; de Bruijn, J.D.; Koole, R.; van Blitterswijk, C.A. Cell based bone tissue engineering in jaw defects. Biomaterials 2008, 29, 3053-3061. [CrossRef] [PubMed]

394. Klein-Nulend, J.; Bacabac, R.; Mullender, M. Mechanobiology of bone tissue. Pathol. Biol. 2005, 53, 576-580. [CrossRef] [PubMed]

395. Kronenthal, R.L. Biodegradable polymers in medicine and surgery. In Polymers in Medicine and Surgery; Springer: Berlin, Germany; Heidelberg, Germany, 1975; pp. 119-137.

396. Sheikh, Z.; Zhang, Y.L.; Grover, L.; Merle, G.; Tamimi, F.; Barralet, J. In vitro degradation and in vivo resorption of dicalcium phosphate cement based grafts. Acta Biomater 2015. [CrossRef] [PubMed]

397. Giocondi, J.L.; EI-Dasher, B.S.; Nancollas, G.H.; Orme, C.A. Molecular mechanisms of crystallization impacting calcium phosphate cements. Philos. Trans. R. Soc. Lond. A 2010 , 368, 1937-1961. [CrossRef] [PubMed]

398. Oberle, A.; Theiss, F.; Bohner, M.; Muller, J.; Kastner, S.B.; Frei, C.; Zlinszky, K.; Wunderlin, S.; Auer, J.A.; von Rechenberg, B. Investigation about the clinical use of brushite-and hydroxylapatite-cement in sheep. Schweizer Archiv Tierheilkunde 2005, 147, 482-490. [CrossRef] [PubMed]

399. Frayssinet, P.; Gineste, L.; Conte, P.; Fages, J.; Rouquet, N. Short-term implantation effects of a dcpd-based calcium phosphate cement. Biomaterials 1998, 19, 971-977. [CrossRef]

400. Grossardt, C.; Ewald, A.; Grover, L.M.; Barralet, J.E.; Gbureck, U. Passive and active in vitro resorption of calcium and magnesium phosphate cements by osteoclastic cells. Tissue Eng. Part A 2010, 16, 3687-3695. [CrossRef] [PubMed] 
401. Grover, L.M.; Gbureck, U.; Wright, A.J.; Tremayne, M.; Barralet, J.E. Biologically mediated resorption of brushite cement in vitro. Biomaterials 2006, 27, 2178-2185. [CrossRef] [PubMed]

402. Ohura, K.; Bohner, M.; Hardouin, P.; Lemaitre, J.; Pasquier, G.; Flautre, B. Resorption of, and bone formation from, new beta-tricalcium phosphate-monocalcium phosphate cements: An in vivo study. J. Biomed. Mater. Res. 1996, 30, 193-200. [CrossRef]

403. Ikenaga, M.; Hardouin, P.; Lemaitre, J.; Andrianjatovo, H.; Flautre, B. Biomechanical characterization of a biodegradable calcium phosphate hydraulic cement: A comparison with porous biphasic calcium phosphate ceramics. J. Biomed. Mater. Res. 1998, 40, 139-144. [CrossRef]

404. Bohner, M.; Theiss, F.; Apelt, D.; Hirsiger, W.; Houriet, R.; Rizzoli, G.; Gnos, E.; Frei, C.; Auer, J.A.; von Rechenberg, B. Compositional changes of a dicalcium phosphate dihydrate cement after implantation in sheep. Biomaterials 2003, 24, 3463-3474. [CrossRef]

405. Penel, G.; Leroy, G.; Leroy, N.; Behin, P.; Langlois, J.M.; Libersa, J.C.; Dupas, P.H. Raman spectrometry applied to calcified tissue and calcium-phosphorus biomaterials. Bull. Group. Int. Rech. Sci. Stomatol. Odontol. 2000, 42, 55-63. [PubMed]

406. Bohner, M.; Merkle, H.P.; Lemaitre, J. In vitro aging of a calcium phosphate cement. J. Mater. Sci. Mater. Med. 2000, 11, 155-162. [CrossRef] [PubMed]

407. Jiang, W.G.; Chu, X.B.; Wang, B.; Pan, H.H.; Xu, X.R.; Tang, R.K. Biomimetically triggered inorganic crystal transformation by biomolecules: A new understanding of biomineralization. J. Phys. Chem. B 2009, 113, 10838-10844. [CrossRef] [PubMed]

408. Flautre, B.; Lemaitre, J.; Maynou, C.; Van Landuyt, P.; Hardouin, P. Influence of polymeric additives on the biological properties of brushite cements: An experimental study in rabbit. J. Biomed. Mater. Res. A 2003, 66, 214-223. [CrossRef] [PubMed]

409. Tamimi, F.M.; Torres, J.; Tresguerres, I.; Clemente, C.; Lopez-Cabarcos, E.; Blanco, L.J. Bone augmentation in rabbit calvariae: Comparative study between bio-oss ( $\mathrm{r}$ ) and a novel beta-TCP/DCPD granulate. J. Clin. Periodontol. 2006, 33, 922-928. [CrossRef] [PubMed]

410. Klammert, U.; Reuther, T.; Jahn, C.; Kraski, B.; Kubler, A.C.; Gbureck, U. Cytocompatibility of brushite and monetite cell culture scaffolds made by three-dimensional powder printing. Acta Biomater. 2009, 5, 727-734. [CrossRef] [PubMed]

411. Klammert, U.; Reuther, T.; Blank, M.; Reske, I.; Barralet, J.E.; Grover, L.M.; Kubler, A.C.; Gbureck, U. Phase composition, mechanical performance and in vitro biocompatibility of hydraulic setting calcium magnesium phosphate cement. Acta Biomater. 2010, 6, 1529-1535. [CrossRef] [PubMed]

412. Le Nihouannen, D.; Hacking, S.A.; Gbureck, U.; Komarova, S.V.; Barralet, J.E. The use of rankl-coated brushite cement to stimulate bone remodelling. Biomaterials 2008, 29, 3253-3259. [CrossRef] [PubMed]

413. De la Riva, B.; Sanchez, E.; Hernandez, A.; Reyes, R.; Tamimi, F.; Lopez-Cabarcos, E.; Delgado, A.; Evora, C. Local controlled release of VEGF and PDGF from a combined brushite-chitosan system enhances bone regeneration. J. Controll. Release 2010, 143, 45-52. [CrossRef] [PubMed]

414. Silva, I.; Branco, J. Rank/Rank1/opg: Literature review. Acta Reumatol. Port. 2010, 36, 209-218. 
415. Sachlos, E.; Czernuszka, J. Making tissue engineering scaffolds work. Review: The application of solid freeform fabrication technology to the production of tissue engineering scaffolds. Eur. Cell Mater. 2003, 5, 39-40.

416. Guo, B.; Lei, B.; Li, P.; Ma, P.X. Functionalized scaffolds to enhance tissue regeneration. Regen. Biomater. 2015, 2, 47-57. [CrossRef] [PubMed]

417. Young, J.; Teumer, J.; Kemp, P.; Parenteau, N. Approaches to Transplanting Engineered Cells and Tissues; RG Landes Co.: Austin, TX, USA, 1997.

418. Kokubo, T. Bioceramics and Their Clinical Applications; Elsevier: Amsterdam, The Netherlands, 2008.

419. Thompson, D.E.; Agrawal, C.M.; Athanasiou, K. The effects of dynamic compressive loading on biodegradable implants of 50-50\% polylactic acid-polyglycolic acid. Tissue Eng. 1996, 2, 61-74. [CrossRef] [PubMed]

420. Ingber, D.E. Tensegrity: The architectural basis of cellular mechanotransduction. Annu. Rev. Physiol. 1997, 59, 575-599. [CrossRef] [PubMed]

421. Chen, C.S.; Mrksich, M.; Huang, S.; Whitesides, G.M.; Ingber, D.E. Geometric control of cell life and death. Science 1997, 276, 1425-1428. [CrossRef] [PubMed]

422. Zhong, S.; Teo, W.E.; Zhu, X.; Beuerman, R.W.; Ramakrishna, S.; Yung, L.Y.L. An aligned nanofibrous collagen scaffold by electrospinning and its effects on in vitro fibroblast culture. J. Biomed. Mater. Res. Part A 2006, 79, 456-463. [CrossRef] [PubMed]

423. Xu, C.; Inai, R.; Kotaki, M.; Ramakrishna, S. Aligned biodegradable nanofibrous structure: A potential scaffold for blood vessel engineering. Biomaterials 2004, 25, 877-886. [CrossRef]

424. Li, D.; Xia, Y. Electrospinning of nanofibers: Reinventing the wheel? Adv. Mater. 2004, 16, 1151-1170. [CrossRef]

425. Yang, S.; Leong, K.-F.; Du, Z.; Chua, C.-K. The design of scaffolds for use in tissue engineering. Part II. Rapid prototyping techniques. Tissue Eng. 2002, 8, 1-11. [CrossRef] [PubMed]

426. Sobral, J.M.; Caridade, S.G.; Sousa, R.A.; Mano, J.F.; Reis, R.L. Three-dimensional plotted scaffolds with controlled pore size gradients: Effect of scaffold geometry on mechanical performance and cell seeding efficiency. Acta Biomater. 2011, 7, 1009-1018. [CrossRef] [PubMed]

427. Moroni, L.; de Wijn, J.; van Blitterswijk, C. 3D fiber-deposited scaffolds for tissue engineering: Influence of pores geometry and architecture on dynamic mechanical properties. Biomaterials 2006, 27, 974-985. [CrossRef] [PubMed]

428. Preechawong, D.; Peesan, M.; Supaphol, P.; Rujiravanit, R. Preparation and characterization of starch/poly (L-lactic acid) hybrid foams. Carbohydr. Polymers 2005, 59, 329-337. [CrossRef]

429. Karageorgiou, V.; Kaplan, D. Porosity of 3D biomaterial scaffolds and osteogenesis. Biomaterials 2005, 26, 5474-5491. [CrossRef] [PubMed]

430. Vander, A.; Sherman, J.; Luciano, D. Humanphysiology: The Mechanisms of Body Function; William C Brown Pub.: St. Louis, MO, USA, 1980.

431. Hokugo, A.; Kubo, Y.; Takahashi, Y.; Fukuda, A.; Horiuchi, K.; Mushimoto, K.; Tabata, Y.; Morita, S. Prefabrication of vascularized bone graft using guided bone regeneration. Tissue Eng. 2004, 10, 978-986. [CrossRef] [PubMed] 
432. Ren, L.-L.; Ma, D.-Y.; Feng, X.; Mao, T.-Q.; Liu, Y.-P.; Ding, Y. A novel strategy for prefabrication of large and axially vascularized tissue engineered bone by using an arteriovenous loop. Med. Hypotheses 2008, 71, 737-740. [CrossRef] [PubMed]

433. Freed, L.; Hollander, A.; Martin, I.; Barry, J.; Langer, R.; Vunjak-Novakovic, G. Chondrogenesis in a cell-polymer-bioreactor system. Exp. Cell Res. 1998, 240, 58-65. [CrossRef] [PubMed]

434. Chen, R.R.; Mooney, D.J. Polymeric growth factor delivery strategies for tissue engineering. Pharm. Res. 2003, 20, 1103-1112. [CrossRef] [PubMed]

435. Engin, N.O.; Tas, A.C. Manufacture of macroporous calcium hydroxyapatite bioceramics. J. Eur. Ceram. Soc. 1999, 19, 2569-2572. [CrossRef]

436. Cama, G.; Barberis, F.; Botter, R.; Cirillo, P.; Capurro, M.; Quarto, R.; Scaglione, S.; Finocchio, E.; Mussi, V.; Valbusa, U. Preparation and properties of macroporous brushite bone cements. Acta Biomater. 2009, 5, 2161-2168. [CrossRef] [PubMed]

437. Habibovic, P.; Gbureck, U.; Doillon, C.J.; Bassett, D.C.; van Blitterswijk, C.A.; Barralet, J.E. Osteoconduction and osteoinduction of low-temperature 3D printed bioceramic implants. Biomaterials 2008, 29, 944-953. [CrossRef] [PubMed]

(C) 2015 by the authors; licensee MDPI, Basel, Switzerland. This article is an open access article distributed under the terms and conditions of the Creative Commons Attribution license (http://creativecommons.org/licenses/by/4.0/). 